\title{
PATHWAYS, BACKGROUND AND OUTCOMES OF THE TRANSITION TO ADULTHOOD IN THE EARLY 2000S IN HUNGARY* Lívia Murinkó
}

\section{ABSTRACT}

In the present paper, we analyze the process of the transition to adulthood in contemporary Hungary. We identify typical pathways, describe them in terms of role transitions, as well as regarding their socio-economic and family background and various outcomes. In order to do so, we regard the transition to adulthood as a multi-dimensional and dynamic process. Using longitudinal data from four waves of the Hungarian Generations and Gender Survey (2001-2012), we apply the method of two-step latent class analysis to study the 1981-1983 birth cohort between ages $18-20$ and $29-31$.

Our results indicate that the transitory period between adolescence and adulthood can be characterized by quite different role configurations. Four different pathways were identified. The most common one is characterized by prolonged education and delayed family formation (51\%). Every fourth young person become employed early and form their own family late (24\%), while $17 \%$ belongs to the early family formation group. Interestingly, the pathway that resembles a standard, linear model of transition to adulthood the most (rapid family formation after prolonged education) is the least frequent (9\%). The four different pathways differ regarding their background and outcomes. Our results suggest that both becoming independent "too early" and "being stuck" in the postadolescent life phase may be associated with social disadvantage and

* This paper is a slightly revised version of the following Hungarian article: Murinkó L. (2019). A felnőtté válás életúttípusai, előzményei és kimenetei a 2000-es években Magyarországon. Demográfia, 62(2-3), 153-198. 
they contribute to the transmission of social disadvantage across generations. Contrastingly, following the pathway of rapid family formation after prolonged education is a kind of "social privilege" and often leads to the most advantageous socio-economic status and wellbeing at around age 30.

Keywords: transition to adulthood, life course analysis, latent class analysis, Generations and Gender Survey, Hungary

Lívia Murinkó,

Hungarian Demographic Research Institute, Budapest, Hungary

E-mail: murinko@demografia.hu

\section{INTRODUCTION}

In past decades, the process of transitioning to adulthood have transformed. Life events traditionally associated with adulthood have been delayed in many cases and have even not occurred in some. The transition to adulthood has become extended in time, while life courses have become more divergent and irregular, in effect transforming the way youth become of age (e.g. Billari and Liefbroer, 2010; Furstenberg et al., 2003, 2004; Liefbroer, 1999; Settersten, 2006; Shanahan, 2000; Somlai, 2007, 2010; Wallace and Kovatcheva, 1998).

Corresponding to these changes, there has been increased scholarly interest concerning the process of the transition to adulthood since the millennium, and larger number of researchers have been studying the phenomenon by using quantitative methods and the life course perspective, exploring and analyzing the multidimensional nature of it. There are two commonly used holistic methods to identify and characterize typical pathways: sequence analysis (Billari, 2001) and latent class analysis (Macmillan and Eliason, 2003). The extensive use of these methods has been made possible by the appearance of more sophisticated statistical softwares and follow-up or retrospective surveys on the multidimensional characteristics of young adults.

Recent studies applying sequence analysis have often made comparisons between youth in different countries and/or different cohorts. Examples being the works of Elzinga and Liefbroer (2007), who compared nineteen, mostly European countries; Lesnard, Cousteaux, Chanvril and Le Hay (2016), who compared twenty; and Schwanitz (2017), who compared eight European countries. 
Hungary was included in all three of these studies. However, on the one hand, these studies looked at older cohorts who were born in the decades after the Second World War, and did not provide much information on what happened in the new millennium. On the other hand, they did not look at national specificities in the transition to adulthood; thus, they provided little insight for those who are interested in country-specific patterns. At the same time, the other frequently used multidimensional method to analyze transition to adulthood from a life course perspective, the latent class analysis, has almost exclusively been applied to construe data collected in the US (e.g. Amato et al., 2008; Macmillan and Billari, 2012; Macmillan and Copher, 2005; Macmillan and Eliason, 2003; Manzoni, 2016; Oesterle et al., 2010; Osgood et al., 2005), with one exception from Norway (Skogbrott Birkeland et al., 2014).

Extensive research has also been done on young adults in Hungary in light of the transformation in how new generations come of age. Numerous studies had focused on the living conditions, desires, aspirations of youth becoming of age, while some studies looked at different key life events connected to this phase. However, as far as we are concerned there has not been any research that grasped the multidimensional and dynamic nature of the transition to adulthood in Hungary. ${ }^{2}$

This study will enrich and complement literature on the transition to adulthood by observing dynamic changes, centering around the transition to adulthood of Hungarian youth in the early 2000s. An additional novelty in the approach of this study is that it will also focus on the background and consequences of pathways. Childhood family context and socio-economic background affect the transition to adulthood; and they are also, directly and indirectly, affecting educational and professional careers, household and family formation. In the process of transition to adulthood, some significant decisions (or the absence of decisions) can have an impact on someone's life for decades to come (Lui et al., 2014). Contrary to the importance of this issue, research that connects and identifies pathways with precursors and outcomes is scarce. This is likely due to the limited availability of suitable follow-up surveys. Such inquiries have been done for example on data from Finland (Räikkönen et al., 2012; Salmela-Aro et al., 2014), Norway (Skogbrott

\footnotetext{
'See for example the "Youth" large-sample survey series conducted every fourth years and analyses based on the these data (Bauer and Szabó, 2005; Szabó and Bauer, 2009; Szabó et al., 2002; Székely, 2013; Székely and Szabó, 2016; Kabai et al. 2018).

${ }^{2}$ Bognár (2007) tried something similar: using retrospective data from the first wave of the Turning Points of the Life Course survey, she looked for signs of de-standardization in the changes in the transition to adulthood of Hungarian youth in past decades. By applying cluster analysis, she identified typical life situations at ages of 25 and 30 of consecutive cohorts, but she did not link age-specific transitions to trajectories.
} 
Birkeland et al., 2014) and the US (Amato et al., 2008; Lui et al., 2014; Mortimer, 2012; Oesterle et al., 2010; Osgood et al., 2005).

The present analysis aims to identify the typical pathways between the ages of 18 and 31, with regards to schooling, work, living with parents, partnerships and parenthood. We characterize different pathways by looking at role transitions, then we look at the background of 18-20-year-olds and compare them to their 29-31-yearold selves based on different variables: demographic situation, socio-economic status, health, wellbeing, values and intentions. The scope of our study enables us to look at the transition to adulthood as a dynamic, multidimensional process and allows us to consider youth to have different life courses. We conduct our analysis on the longitudinal data gathered through the Hungarian Generations and Gender Survey. We follow the life course of the 1981-1983 birth cohort between ages 18 to 31, applying the method of two-step latent class analysis.

\section{THEORETICAL FRAMEWORK}

\section{Prolonged transition to adulthood and the life course}

Due to structural and ideational changes of past decades, the process of the transition to adulthood has transformed (e.g. Billari and Liefbroer, 2010; Furstenberg et al., 2003, 2004; Liefbroer, 1999; Settersten, 2006; Shanahan, 2000; Somlai, 2007, 2010; Wallace and Kovatcheva, 1998). The age of reaching adult status has generally increased, and adult status itself has become more challenging to define. Young people reach certain steps of adulthood at different ages (if they do so at all): entering adulthood is not a single step but a gradual and multidimensional transition. The different milestones during this process are reversible, except for entering parenthood. As a result, instead of the emergence of a new standard life course, the heterogeneity of experiences has increased. The timing and the ordering of important life course events during the transition to adulthood show great individual variation (Brückner and Mayer, 2004; Liefbroer, 1999).

The most commonly used theoretical framework for studying the process of transition to adulthood is the life course approach. It states that the mutual interaction of different social roles and their unfolding trajectories over time pave the way of the transition to adulthood (or for the whole life course for that matter). Personal life choices and the immediate environment determine what roles youth take on, but the broader social, economic and cultural contexts also influence this process. They all affect the sequencing of these roles, and how 
youth enter into, pass through and emerge from certain social institutions. Thus, we can view the life course as a sequence of social role configurations and the transitions between them, which evolve in several interconnected dimensions of life (Elder, 1985; Macmillan and Copher, 2005).

According to more traditional sociological and demographic approaches, adolescents become adults through assuming certain roles during life course transitions (George, 1993; Hogan and Astone, 1986; Modell et al., 1976). After finishing their studies and entering the labor market, they turn from dependent students to socially and financially independent employees. After leaving the parental home, they establish residential independence. After forming a stable relationship, starting a cohabiting union and/or getting married, formerly single people become partners or spouses. Moreover, childbearing makes childless people parents. Most demographic literature on the transition to adulthood study the timing and the ordering, sometimes also the determinants and the consequences of these life course events. However, they often look at the different transitions separately or use cross-sectional data to analyze the connection between them.

Some criticize the transition-based approach to the transition to adulthood (e.g. Arnett, 2000; Manzoni, 2016; Robette, 2010). The main points of criticism being that it does not take into account that some of these transitions are reversible, not all life events are experienced by everyone, and that transitions are often gradual. For example, leaving the family household, transitioning from education to employment and moving in with a partner for the first time can all be complex and lengthy processes in themselves, in which most go through transient phases of partial independence. Analysis shows, however, that conventional markers of adulthood remain essential for individuals to see themselves as adults (Shanahan et al., 2005). ${ }^{3}$

We cannot give a full account of the theoretical models of the transition to adulthood here. Instead, we introduce a model that describes how the process of the transition to adulthood has changed with the help of role transitions. Galland (2004) has developed two models for the patterns of transitions experienced by young people in most advanced societies (Western Europe) in the 1950s-1960s and afterwards (Figure 1). These models are based on the typical life course of men. In the "post-war transition model" (A), there was a clear separation be-

\footnotetext{
${ }^{3}$ Apart from the role-based approach of the transition to adulthood, further criteria may be necessary in determining whether someone has become of age in one's perspective and in the eyes of society. For example, self-definition and phycological aspects also have to be considered (e.g. Arnett, 2000; Vaskovics, 2000; also see a summary in Murinkó, 2010).
} 
tween the public and the private spheres and between childhood/teenagehood and adulthood. In the public sphere, young people finished compulsory schooling, then they entered the labor market and became financially independent. The developments in the domestic sphere were synchronous to changes in the public domain. After the end of their studies, young people could leave their parental home, get married and start a family. Transition to adulthood was a linear process; events were timed and ordered according to a standard pattern.

Contrastingly, this pattern has changed during the past decades ("extended transition model", B, Figure 1). The period of the transition to adulthood has been prolonged and especially its endpoint has become hard to define. The relationship between events related to education, work, partnership and family has weakened. Young people study longer, often in tertiary education. Many of them go through a period of precarity (unemployment, part-time jobs or fixed-term contracts) before they find a stable job. The difficulty of becoming financially independent also inhibits residential independence and family formation. Young people often live alone for some time before moving in together with a partner or spouse.

Figure 1: Two theoretical models of the transition to adulthood
A) The post-war transition model
B) The extended transition model

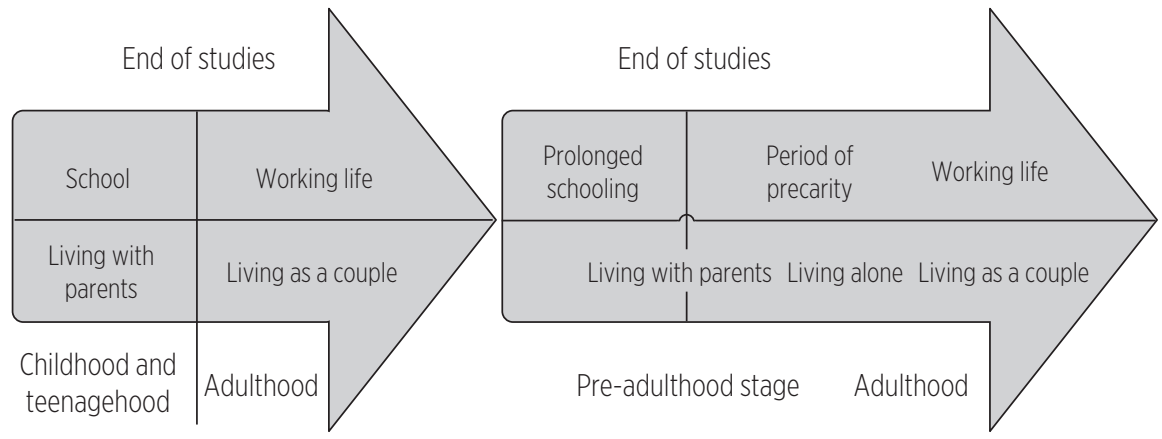

Source: Galland, 2004, p. 137., 151.

Some authors claim that the prolonged transitory period between adolescence and (young) adulthood had been institutionalized and can be regarded as a separate phase of the life course (Arnett, 2000; Côtè, 2000; Furstenberg et al., 2004; Keniston, 1968; Klein, 1990). During this phase, young people are already of full age but have not entered all the statuses that are habitually associated 
with being adult: they delay family formation, especially parenthood, they stay in school, they continue to live in (or return to) the parental household, and/or they do not have stable full-time jobs. Various terms are used for this transitory period, such as postadolescence (Kenniston, 1968), youth (Klein, 1990), emerging adulthood (Arnett, 2000), or youthhood (Côtè, 2000).

There are two opposing discourses about the prolonged transition to adulthood. The first one claims that young people have become reluctant to "grow up"; they avoid responsibility and postpone important life course transitions in order to take advantage of the comfort of the parental household (they live in the "Hotel Mama", see Herms-Bohnhoff, 1993) and use the parental resources as long as possible (Arnett, 2000). The second discourse emphasizes that the prolonged and transformed process of the transition to adulthood is a coping strategy, a rational reaction to the changing opportunities, precarious conditions and economic difficulties that young people face nowadays (Côtè and Bynner, 2008). The multiplication of life course options has opened up many opportunities; however, the short- and long-term consequences of decisions are unpredictable (Mills and Blossfeld, 2003). It increases feelings of insecurity and doubt, and it may deepen the identity crisis - the so-called quarter life crisis - that characterizes some young adults in their twenties and early thirties (Robbins and Wilner, 2001).

\section{Social differences, background and outcomes}

As individual pathways have become more heterogeneous, youth with different socio-economic and family background follow divergent paths to adulthood, and the length of postadolescence also shows significant individual differences. Differential pathways are results of the combined effect of family background and individual decisions, that are in turn shaped by socialization, personal preferences, different opportunities and constraints stemming from the immediate and broader context. Thus, the transition to adulthood is a critical life stage (also in this respect), because advantages and disadvantages are accumulated along the way and determine one's prospects, resources, health and wellbeing at later stages of their lives (Arnett, 2000; Furstenberg, 2008; Lui et al., 2014; Mortimer, 2012; Billari et al. 2019).

The amount of transfers received from parents play a prominent role during the transition to adulthood. Parental support is indispensable in certain life stages, for instance when youth are still in education or starting up enterprises. More- 
over, the assistance provided by parents through financial, housing or emotional means also remains crucial later on in life, for example, in crises like losing a job or going through a divorce. This is especially true in the case of singles because they cannot rely on the support of their partner (Mortimer, 2012)

It is an essential question, therefore, is what we know about social differences in the transition to adulthood. Regarding the effect of parental background, young people in their late teens and on the verge of becoming adults hold very different resources, opportunities and skills (Furstenberg, 2008). According to international theoretical literature, postadolescence may be longer for those who receive financial support from their parents, who have a stronger safety net, allowing them to devote more time to learning, personal development and experimentation before deciding on what adult roles they want to choose for themselves (Arnett, 2000; Schoon, 2014; Billari et al., 2019). More disadvantaged youth, however, need to "grow up faster" because they are forced to leave school in order to get employment, while they also on average have children at a younger age (Furstenberg et al., 2004). However, the opposite is also conceivable: young people may not make a conscious decision, regardless of their circumstances, in postponing to take up specific adult roles, instead they may not hold the sufficient resources to be able to enter those roles due to their disadvantaged background (Côtè and Bynner, 2008).

According to Elder (1975), there is an "ideal" age for taking up adult roles, that is, those who assume these roles too early or too late are less successful in integrating into adult society. Who become adults too early may lack psycho-social and socio-economic resources and may also be less prepared for adult responsibilities. While those who become adults late spend too much time in a semi-independent, transitional phase, making it more difficult for themselves to adapt to adult roles. In itself, it can be disadvantageous for youth to experience life events at an age other than the majority does - possibly even considered deviant - because they do not coincide with their other role transitions or expectations created by institutional structures. It can also affect youth negatively if they do not go through role transitions in the usual order, and as a consequence, they may be less able to deal with differential expectations associated with each role (Elder, 1975).

Thus too early and too late transitions can both have negative consequences, although the process of transitioning to adulthood has become greatly destandardized and age norms have weakened. According to empirical research, those who have followed the "normative" pathway to adulthood are in the most favorable position (Mortimer, 2012). Early adoption of adult roles (early parent- 
hood, leaving schooling early on to secure employment) is often linked to relatively low social status later on, while late role transitions (mainly due to the spill-over effect of prolonged education) are linked to higher social status (Lui et al., 2014; Mortimer, 2012).

\section{TRANSITION TO ADULHOOD IN HUNGARY}

\section{Family formation, transition from education to employment and housing}

In Hungary, young people on the doorstep of adulthood faced completely different socio-economic circumstances after 1989-1990 than previously due to the deep political, social and economic transformation (Domonkos, 2010; Macura and Mochizuki-Sternberg, 1999). The economic crisis and the resulting financial and employment insecurities have also had demographic consequences. They have contributed to a drastic fertility decline, postponement of family formation, increasing number of extramarital births, decreasing popularity of marriage and increasing popularity of nonmarital unions. The economic recession, employment precarity, unemployment and the financial insecurity of youth and their parents have also affected the possibility to establish independent households, delaying the attainment of financial and residential independence (Beck and Beck-Gernsheim, 2002).

In the two decades following 1990, family formation was postponed, cohabitation became more widespread - especially among young people -, and fertility rates declined (Spéder, 2007). The mean age at marriage among women increased from 22 to 28.7 years, and for man from 24.7 to 31.4 years between 1990 and 2010, while more and more people choose not to marry altogether. For women, the mean age at first birth was 23 in 1990 and 28.2 years twenty years later. The share of extra-marital births increased from $13.1 \%$ to $40.8 \%$ during the same period (Központi Statisztikai Hivatal [KSH], 2016).

(Youth) unemployment appeared in the 1990s and has become permanent for some groups, especially for people with low education. Entering the (primary) labor market has become more difficult or even impossible for some. First jobs are often precarious and poorly paid. As a response to this situation, young people may prolong their education, and the expansion of higher education has made it possible (Bukodi and Róbert, 2005; Laki 2006). As a result of the steady expansion of higher education in the 1990s, the proportion of students quadru- 
pled between 1990 and 2008, out of which the rate of part-time students (students of correspondent, distance and evening curses) grew the most (Kozma, 2010). The expected length of schooling has been extended from 13.8 to 17.8 years since 1990; in other words, a child who starts school at age seven is expected to finish it at age 25, instead of 21 (Organisation for Economic Co-operation and Development, 2000, 2010). The expansion of higher education has come to an end after 2008 (Hives and Kozma, 2014), while more and more people take part in other forms of education (secondary or higher vocational training, other courses, etc.) (Széll and Nagy, 2018). Despite the expansion, socio-economic background has an increasing impact on the educational pathway of young people, and the children of lower-educated fathers have a low and decreasing chance to continue education at higher levels (Széll and Nagy, 2018).

The transitional period between leaving the educational system and integrating into the labor market has been extended since the 1990s (Vincze, 2012). What used to be a linear, predictable school-to-work pathway has become fragmented and heterogeneous. Training at successive educational levels and the transition from school to the labor market is no longer necessarily linear; instead, they are characterized by longer or shorter intermissions, various trainings, concurrent studying and labor, migration experience, sometimes appearing alternately or parallel to each other in life courses of youth (Nyüsti, 2013; Széll and Nagy, 2018). A significant proportion of young people are unemployed for some time after leaving education, in particular those with lower education (Bene et al., 2018).

After the regime change in 1989, previously existing problems and tensions around the access to housing for young people have not been resolved; furthermore, new issues have arisen. As a result of an almost complete privatization, social housing has become very limited and favors families. The private rental market is expensive and considered only a temporary solution by both tenants and landlords. Ownership is the most common and usually the only way of obtaining an own flat or house. Lacking individual or family resources, young people postpone or forgo leaving the parental home (Murinkó, 2009; Spéder et al., 2009). After the regime change, the public and the banking sectors practically withdrew from housing financing and only reappeared after about ten years. The expansion of home mortgage loans played a significant role in improving home acquisition opportunities for young people between 2000 and 2008 (KSH, 2012). After 1999, housing investment and lending started increasing rapidly (KSH, 2005), then declined again after 2009 due to the financial crisis (KSH, 2012).

In the 2000s, the median age for moving out of the parental household was 25 for women and 27 for men, and by the age of $35,81 \%$ of women and $77 \%$ of 
men had left their parents' home (though some returned later) (Murinkó, 2009). Compared to adult children in their twenties, those in their thirties (or older) living with their parents are more typically adapting to financial or housing difficulties (Ahmed and Emigh, 2005; de Jong Gierveld et al., 2002), or resort to the "safety net" of their parents as they go through life crises (e.g. divorce, unemployment) (Monostori and Murinkó, 2019).

The economic recession that started in 2009 harmed the economic conditions of young people (and the whole society) not only from the perspective of housing. Youth unemployment substantially increased, and more people lived with their parents (Medgyesi and Nagy, 2014). During the years of recession, young people were hit harder by unemployment than other age groups, finding a job was more difficult and took more time for them, and also their personal expectations about their labor market prospects became more pessimistic (Gazsó, 2013). The ratio of housing maintenance expenditure to household income increased between 2000 and 2009 among all age groups and household types but remained the lowest among parent(s) with adult children and the highest among young and middle-aged single adults (KSH, 2012).

\section{Pathways of transition to adulthood in Hungary}

As mentioned earlier, no quantitative analysis explicitly focusing on youth in Hungary has been conducted to analyze the complex process of transition to adulthood using retrospective or follow-up panel data. However, some international comparative studies were made that included Hungarian data.

Lesnard et al. (2016) identified fourteen pathways to adulthood based on a study that looked at people born between 1905 and 1971, and their pathways from the ages of 18 to 35, in twenty European countries. In Hungary the most common pathway to adulthood was the early category (35\% of the 1945-1959 cohort and $31 \%$ of those born in the 1960s belonged to this category), where young people started working at the relatively early age of 18-20, left their parents' household, moved in with a partner, got married and had their first child shortly afterwards. These life events were experienced in a relatively short period, and youth in those cohorts took on adult roles rather soon. The late start of employment was also typical (13-16\% per cohort): their first job was acquired at a median age of 21 years, the establishment of independent households followed relatively quickly, but they only started their own families in their late twenties. For those who left their parents' home late (12-20\% of the 1945-1959 cohort, 14\% of the 1960-1969 cohort) or 
very late (4-8\%), early employment was followed by late home-leaving and late partnership formation. One-quarter of the very late movers still lived with their parents at the end of the observation period, and about one-third of the group did not start their own family. Approximately one-third of the sample made up the remaining ten types of pathways to adulthood, each with a shallow frequency.

Sequence analysis of Schwanitz (2017) on a pooled sample of eight European countries identified seven pathways to adulthood in studying life events between the ages of 18 and 34 of those who were born between 1951 and 1978. The largest group within Hungary was comprised of youth who left their parents' household late (25\%): they completed their studies relatively early, were mostly single, while a small proportion of them started their own family living in the parents' home. A similar proportion made up the "modern and independent" type (23\%): young adults in this category started working early, and soon afterwards established their own households, but only formed partnerships later on. All life events were timed relatively late by members of the "studying with a cohabiting partner" group (13\%). A more traditional pattern was followed by $13 \%$, who quickly went from school into work, got married, and had a child. The group of "working cohabitees" (10\%) entered the labor market and typically formed a partnership early on. The group of people with late transitions and late independence (10\%) started their own families especially late. The smallest group was made up of people of "slow transitions with inactivity" (7\%): they finished their studies early on, but started to work at a lower rate and rather late. Low-educated youth were overrepresented among those who followed the more traditional path, those who left their parent's household later and among the late and inactive group. At the same time, university graduates were overrepresented in the modern and independent, the late transitioners with independence, and the studying with cohabiting partner groups.

Results regarding the role of parental resources in the prolonged transition to adulthood in Hungary are non-conclusive. Some authors found that the lengthening of the transitory period between adolescence and adulthood comes with the arrival of a new group of consumers and the growing middle class, who can afford to postpone taking adult roles (Gábor, 2000). Results from other studies (Gazsó and Laki, 2004; Kapitány, 2006) suggest that the prolonged transition to adulthood is not a privilege that has spread from the upper social strata downwards but rather a kind of constraint, and postadolescence becomes a persistent condition as a result of disadvantaged social conditions. The contradictory view of the Hungarian situation reflects the double judgement tracible in the international literature (see the debate of Arnett, 2000 and Côtè and Bynner, 2008). Ac- 
cording to this, prolonging the transition to adulthood may be a lifestyle choice for some who do not (at least for a while) want to take on traditional adult roles; but it is inevitable for others, who would choose to do so, yet in vain, cannot "become of age". In my opinion, the two approaches are not mutually exclusive, but depending on the social situation of the individual one prevails over the other.

\section{Social and demographic factors in the life course patterns of the 1981-1983 cohort}

We follow the lives of respondents born between 1981 and 1983 during the analysis. ${ }^{4}$ What characterizes this selected group? Compared to previous years, this is a smaller cohort: for example, in 1975, live births peaked at 185 thousand, while in 1981 only 143 thousand and in 1983 only 127 thousand children were born (KSH, 2015). A relatively small cohort can expect less competition than larger birth groups from nursery school and kindergarten through to university admission and to finding employment (Easterlin, 1978).

Members of the cohort in question were only 6-9 years old at the time of the regime change; thus they may only have childhood memories of state socialism, and the crisis that followed the change of regime only affected them through their parents and families. They completed their primary education in the middle third of the 1990s (if they did so), and they reached the age of 18 around the turn of the millennium. With declining cohort sizes and the increasing number of students enrolled in higher education, it was becoming more accessible to be admitted to college or university, while the proportion of vocational certificate holders was decreasing. By the time this cohort first started working, it was already evident that unemployment and labor market insecurities were part of many people's lives. Compared to previous cohorts, they had broader opportunities in terms of education, occupation, dating, leisure, consuming and travelling. However, in order to be able to take advantage of these opportunities, one needed information and resources that were not equally available to everyone. Member of this cohort were not born into the digital world, yet most of them met with new technologies at a young enough age to be able to use them in an agile fashion. However, about every fifth person aged 20-29 was digitally illiterate in 2008 (Ságvári, 2011). The economic crisis of 2008-2009 hit the 1981-1983 cohort

\footnotetext{
${ }^{4}$ They are the "microgeneration" that is wedged between Generation X and Generation Y ("Millennials") and is called "Xennials" by people of the Internet (see, for example, D'Souza, 2017).
} 
in the second half of their twenties, which likely hindered the establishment of independent households and family formation for those who had not yet gone through these transitions, and also harmed their labor market situation.

\section{RESEARCH QUESTIONS}

The analysis aims to identify the pathways in the process of transition to adulthood and to examine the background and outcomes of each pathway among youth in Hungary in the 2000s. With our inquiry, we are looking to answer to two main research questions.

The first question relates to the types of pathways from adolescence to adulthood that can be differentiated in Hungary in the 2000s. This question is based on the assumption that pathways to adulthood have become diverse; therefore, there are not only one, but several different observable pathways in the context of Hungary. These pathways are characterized by the different timing of each life event and also by the rate at which young adults experience transitions by the end of the study period. According to previous results, there are both "early" and "postponing" patterns, so it is likely that there are groups that go through all role transitions relatively early and that go through all of them relatively late. As well as, some are located between these two extremes and are characterized by different combinations and timing of each life event.

The second question concerns the social differences between the different pathways to adulthood. Do the pathways differ in terms of socio-economic background and outcomes? Which groups get stuck in a partly adolescent, partIy adult situation, and which groups adopt adult roles swiftly? We hypothesize that both early and prolonged transitions to adulthood are less common among young people with a more favorable socio-economic background, while those from disadvantaged backgrounds are more likely to be stuck in semi-adulthood and are more likely to take on adult roles much earlier than the average. Furthermore, we also assume that "too early" and "too late" transitions to adulthood contribute to the intergenerational transmission of social disadvantages.

And finally, at the end of the paper, we return to Galland's (2004) previously described theoretical model, and - taking our empirical results into account - we discuss the necessary changes to adapt the model to contemporary Hungary. 


\section{DATA AND METHODS}

\section{Longitudinal data from the Hungarian Generations and Gender Survey}

In order to answer the above research questions, we need survey data that follows the life course of young people and provides detailed information on their education, labor market and partnership history, as well as on changes of their socio-economic situation. We use longitudinal data from four waves of the Hungarian Generations and Gender Survey ${ }^{5}$ (for more information on the survey, see Murinkó and Spéder, 2016). The basic characteristics of the survey and the sample are summarized in Table 1.

Table 1: Basic characteristics of the four waves of the Turning Points of the Life Course panel survey (the Hungarian Generations and Gender Survey) and the 1981-1983 birth cohort

\begin{tabular}{cccccc}
$\begin{array}{c}\text { Survey } \\
\text { wave }\end{array}$ & $\begin{array}{c}\text { Years of } \\
\text { fieldwork }\end{array}$ & $\begin{array}{c}\text { Total sample } \\
\text { Age of } \\
\text { respondents }\end{array}$ & $N$ & $\begin{array}{c}\text { Our working sample: } \\
\text { the 1981-1983 birth cohort }\end{array}$ \\
\hline 1 & $2001 / 2002$ & $18-75$ & 16363 & $18-20$ & Age of \\
2 & $2004 / 2005$ & $21-78$ & 13540 & $21-23$ & 827 \\
3 & $2008 / 2009$ & $25-82$ & 10641 & $25-27$ & 625 \\
4 & $2012 / 2013$ & $29-86$ & 8103 & $29-31$ & 428
\end{tabular}

Source: Longitudinal data from the Hungarian Generations and Gender Survey (2001-2013), birth cohort 19811983, $n=1000$, author's calculation.

We follow the life course of the 1981-1983 birth cohort ( $n=1000$ ), i.e. young people who were aged 18-20 at the time of the first wave (in 2001) and became 29-31 years old by the fourth wave (2012). All respondents are included in the analysis who belong to the chosen cohort and participated in wave 1. We know only part of the life course of respondents who dropped out after wave 1, but we also take this information into account during the analysis. We present weighted results.

\footnotetext{
${ }^{5}$ The first and the second waves of the Hungarian survey (called Turning Points of the Life Course) correspond to the first wave of the GGS.
} 


\section{Role transitions and typical pathways}

For identifying typical pathways, we need a method that handles the transition to adulthood as a multi-dimensional process and that identifies different pathways that young people follow. We have information on respondents from four waves, when they were in different stages of their lives. We do not study one single transition but a sequence of them. These life-course events are timed and ordered differently for each respondent (and some people do not even go through all transitions during the observation period). We use the method of two-step latent class analysis, which is a variant of latent class analysis (LCA) that is specially adapted for life course analysis (Macmillan and Eliason, 2003). ${ }^{6}$ We use the LCA Stata plug-in (version 1.2.1) by Lanza et al. (2018).

LCA sorts respondents into latent groups based on categorical observed variables. The procedure aims to estimate class membership probabilities for each individual. In the present analysis, the observed variables are the objective dimensions of the transition to adulthood. The roles that are usually associated with becoming adult were measured with the same dummy variables in each wave: (1) participation in full-time education, (2) being employed, ${ }^{7}$ (3) living together with one or both (biological) parents, (4) living with a partner or spouse, and (5) being a parent. Figure 2 shows the proportion of respondents who experienced the five analyzed role transitions by a certain age. ${ }^{8}$

Latent pathways are identified in two steps, with the help of latent class analysis at each step. First, we identify latent role configurations - types of life situations - for each wave of the panel survey separately (cross-sectional analysis). Second, we identify latent pathways based on transitions between latent role configurations in the course of the four subsequent waves (panel analysis). Model statistics for each step - that provide the basis for deciding on the number of classes - are included in Table A7 in the Appendix.

\footnotetext{
${ }^{6}$ For more information on LCA, see Collins and Lanza (2010) and Hagenaars and McCutcheon (2002). Simulation studies showed that LCA identifies pathways more effectively than cluster analysis (Magidson and Vermunt, 2002), and it is just as effective as sequence analysis (Barban and Billari, 2012).

${ }^{7}$ We regard all respondents as employed who are either employees or self-employed, who work full- or part-time, who have permanent or temporary jobs, and also who work while studying or being on childcare leave. In our working sample, the majority (90-95\%) of working respondents have full-time positions as employees or are self-employed.

${ }^{8}$ However, if young people follow different pathways, averages (such as those presented in Figure 2) tell us little about the diverse experience of youth.
} 
Figure 2: The share of respondents who experienced five key role transitions by a certain age in Hungary (2001-2013)

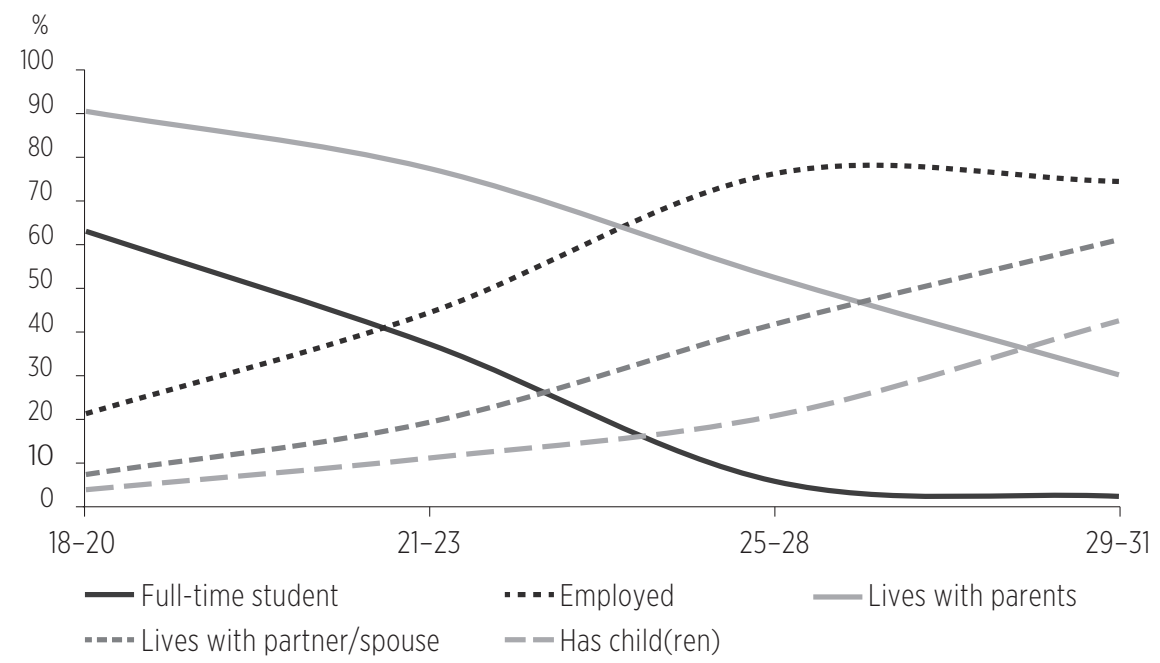

Source: Longitudinal data from the Hungarian Generations and Gender Survey (2001-2013), birth cohort 1981-1983, $n=1000$, author's calculation.

\section{Examining family and social background and outcomes}

In the second part of the analysis, the life circumstances of the youth who are at the beginning of transitioning to adulthood will be described. We measure the precursors of the pathways when members of the cohort were aged between 18 and 20 , and some retrospective variables of family background refer to an earlier period up to the age of 16 . The following variables measure family background. The parents' educational attainment is based on the educational level of the higher educated parent or on the education of only one parent if information on the other parent is not available. There is a variable showing the composition of the family of origin, which makes a distinction between those who were raised in a two-parent household up to the age of 16 , those who lived in a single-parent household (but not with a step parent) for a shorter or longer period, and those who experienced both single- and step-parent spells. Finally, we take into account the number of siblings one grew up with, and those who are of Roma origin. ${ }^{9}$

\footnotetext{
${ }^{9}$ We consider people of Roma origin (1) if they identified themselves as being of Roma or Hungarian of Roma origin in their answer to the ethnicity question, or (2) if they were identified as Roma by the interviewer. We could not differentiate any other ethnic groups in our sample because only $1 \%$ of the respondents indicated an ethnic origin other than Hungarian or Roma.
} 
The own socio-economic position of young people aged between 18 and 20 can only be measured to a limited extent, as a significant proportion of them are still studying or have only been employed for a few years. The analysis takes into account the educational attainment of young people (if they have finished their studies), and in case one is still studying, the level of education at which they are at. The latter has a good chance of projecting the expected (future) highest level of education. In examining the labor market situation, a distinction is made between (self-)employed persons, full-time students, individuals on parental leave, the unemployed, compulsorily conscripted soldiers and other types of inactive people. The latter group includes a few disability pensioners, widow(er)'s pensioners, homemakers and other inactive persons. There are only two or three respondents in the sample who have been working while studying or while being on parental leave, respectively, so we did not establish a separate category for people with double statuses. Since most young people between the ages of 18 and 20 do not have their own income, we use the self-assessment of households' income situation rather than individual income, as well as the lack of certain household goods that most people would like to possess. We regard respondents as materially deprived if they would like to have but cannot afford at least three of the listed items: (1) an apartment in which everyone has a separate room; (2) toilet and bathroom or shower in the apartment; (3) garden, terrace or balcony overlooking pleasant environment; (4) phone; (5) car; (6) color television; (7) automatic washing machine; (8) dishwasher; (9) video recorder; or (10) home computer. Besides, we also consider the type of settlement of the place of residence (Budapest, city, town or village).

Three variables measured the health status and wellbeing of young people: limitation in their every-day activities by some kind of health problem, illness or disability; Ioneliness: ${ }^{10}$ and satisfaction with the course of their life so far (scale from 0 to 10, where higher values indicate a higher level of satisfaction). Respondents who follow the teachings of the church or religious in their own way are treated as religious, and this variable serves as an indicator of personal values.

Respondents' positions at age 29-31 are measured by marital status, partnership status, number of children, type of household, educational level, labor

\footnotetext{
10 "People's general well-being can be influenced by many things. Use card no. 3 and indicate to what extent they apply to you. (1) There is always someone around I can discuss my everyday problems with. (2) I can always rely on someone in case of need. (3) I often feel that no one is interested in what I say. (4) I feel that intimacy and warmth are missing from my life. (5) I often feel lonely." The answer categories were the following: 1 - not at all, 2 - rather not, 3 - partly, 4 - fully applies. The index is computed as the sum of the five values (the first and the second variable are reverse coded), and a higher value indicates higher level of loneliness.
} 
market situation, type of occupation, and financial deprivation. The distinction between household types is based on whether the respondent has a cohabiting partner, whether they live with their parents and whether they have children. We take all those who were employed on fixed-term contracts, as public workers, as interns, or on a seasonal, casual, or alternating basis, as having uncertain employment. Some variables not only reflect the current situation but also refer to life experiences such as unemployment experience, previous long-term relationship or marriage that resulted in breakup or divorce. Because relationship and fertility pathways are not yet concluded at this age, the analysis also includes questions about the intention to have children and to move in with a partner in the future. Besides, we examine young people's religiousness, loneliness, life satisfaction, disability or illness, and smoking.

\section{Limitations}

We also need to acknowledge that the study has some limitations. With regards to the criteria of adulthood used in our analysis, the data do not reveal whether responses reflect the results of the respondent's own decision or whether they are the consequence of external socio-economic constraints." If prolonging the transition to adulthood is, in fact, a coping mechanism for youth who are facing economic hardship and other insecurities, rather than the result of free choice (Côtè and Bynner, 2008), then this aspect must also be taken into account when interpreting the results of our inquiry. However, we cannot evaluate whether respondents chose their situation themselves or whether they were forced into life circumstances despite their differential intentions and plans.

Latent pathways are identified for the whole working sample and not separately for men and women. We present the distribution of men and women by pathways and always introduce gender differences (if there are any) in the description of the background and consequences of the different pathways. However, it is possible that not only different proportions of women and men experience certain pathways but there may be some gender-specific pathways as well. Consequently, further analysis is needed to test if the process of the transition to adulthood is structured differently for women and men. Moreover,

\footnotetext{
${ }^{11}$ This distinction could lead us to look at the role of agency and personal decisions in the life course, in particular in the transition to adulthood, and to what extent it can be measured in a survey. However, the discussion of these ideas would go beyond the scope of the present analysis.
} 
only a small cohort (people born between 1981 and 1983) are analyzed. Their life course and experiences may differ from other cohorts. Consequently, further research should focus on change over time. And finally, studies should go beyond descriptive methods and use regression models on the causes and consequences of different pathways - controlling for potential selection bias - and they should also tackle selective attrition between survey waves.

\section{RESULTS}

\section{Role configurations at certain time points}

In the first step of the analysis, we identified latent classes for each wave separately. The best solution yielded three classes for the ages of 18-20 and 29-31 and four classes for the ages of 21-23 and 25-28 (see Table A7 in the Appendix). The number of classes per age group indicates that the life course of young adults shows the greatest variability during their mid-twenties.

Most 18-20-year-olds (63\%) have not assumed any of the adult roles: they are often full-time students, not employed, live with their parents and do not yet have a partner, a spouse or children (Table 2). At this age, 30\% have finished school and started to work; however, they still live in the parental household in "child status". Only 7\% have their own family (mostly a partner/spouse and maybe also children) but their probability of being employed is only $33 \%$.

At the age of $21-23$, the proportion of full-time students is only $37 \%$, and the biggest group is employed but still lives with their parents in child status (43\%). $10 \%$ have their own family - a partner and children - but they are typically not employed. Another 10\% lives independently from their parents, are employed, have a cohabiting partner or spouse but no children.

Four years later there is no "full-time student" group any more since most young people have already finished education by the age of 25-27. However, 14\% are still "in transition" between school and work, live with their parents and do not have their own family. The "employed, in child status" class is still the most populous group (45\%). 20\% have their own family, and 22\% have assumed all adult roles except parenthood. 
Table 2: Conditional probabilities of different roles and latent class probabilities at four time points during the transition to adulthood in Hungary, 2001-2013

\begin{tabular}{|c|c|c|c|c|c|c|c|c|}
\hline \multirow[b]{2}{*}{$\begin{array}{c}\text { Survey } \\
\text { wave and } \\
\text { year }\end{array}$} & \multirow[b]{2}{*}{$\begin{array}{c}\text { Age of the } \\
\text { 1981-1983 } \\
\text { cohort }\end{array}$} & \multirow[b]{2}{*}{$\begin{array}{c}\text { Name of the latent } \\
\text { class }\end{array}$} & \multicolumn{5}{|c|}{ Roles } & \multirow[b]{2}{*}{$\%$} \\
\hline & & & $\begin{array}{c}\text { Full- } \\
\text { time } \\
\text { student }\end{array}$ & $\begin{array}{l}\text { Emplo- } \\
\text { yed }\end{array}$ & $\begin{array}{l}\text { Lives } \\
\text { with } \\
\text { parents }\end{array}$ & $\begin{array}{c}\text { Lives } \\
\text { with } \\
\text { partner/ } \\
\text { spouse }\end{array}$ & $\begin{array}{l}\text { Has } \\
\text { child- } \\
\text { (ren) }\end{array}$ & \\
\hline \multirow{3}{*}{$\begin{array}{l}\text { Wave } 1 \\
(2001 / 2)\end{array}$} & \multirow{3}{*}{$\begin{array}{l}18-20 \\
\text { years }\end{array}$} & Full-time student & 0.99 & 0.00 & 0.96 & 0.01 & 0.00 & 63.2 \\
\hline & & $\begin{array}{l}\text { Employed, in child } \\
\text { status }\end{array}$ & 0.02 & 0.62 & 0.97 & 0.04 & 0.02 & 29.6 \\
\hline & & Starting own family & 0.01 & 0.33 & 0.22 & 0.75 & 0.38 & 7.2 \\
\hline \multirow{4}{*}{$\begin{array}{l}\text { Wave } 2 \\
(2004 / 5)\end{array}$} & \multirow{4}{*}{$\begin{array}{l}21-23 \\
\text { years }\end{array}$} & Full-time student & 0.97 & 0.00 & 0.94 & 0.02 & 0.00 & 37.1 \\
\hline & & $\begin{array}{l}\text { Employed, in child } \\
\text { status }\end{array}$ & 0.00 & 0.80 & 0.90 & 0.02 & 0.02 & 43.2 \\
\hline & & Starting own family & 0.08 & 0.01 & 0.23 & 0.89 & 0.72 & 9.9 \\
\hline & & Childless adult & 0.00 & 0.99 & 0.16 & 0.87 & 0.04 & 9.8 \\
\hline \multirow{4}{*}{$\begin{array}{l}\text { Wave } 3 \\
(2008 / 9)\end{array}$} & \multirow{4}{*}{$\begin{array}{l}25-27 \\
\text { years }\end{array}$} & In transition & 0.32 & 0.26 & 0.92 & 0.01 & 0.05 & 13.5 \\
\hline & & $\begin{array}{l}\text { Employed, in child } \\
\text { status }\end{array}$ & 0.00 & 0.99 & 0.80 & 0.05 & 0.01 & 44.9 \\
\hline & & Starting own family & 0.00 & 0.43 & 0.11 & 0.95 & 0.96 & 20.0 \\
\hline & & Childless adult & 0.04 & 0.91 & 0.10 & 0.94 & 0.01 & 21.6 \\
\hline \multirow{3}{*}{$\begin{array}{c}\text { Wave } 4 \\
(2012 / 13)\end{array}$} & \multirow{3}{*}{$\begin{array}{l}29-31 \\
\text { years }\end{array}$} & $\begin{array}{l}\text { Employed, in child } \\
\text { status }\end{array}$ & 0.01 & 0.75 & 0.87 & 0.07 & 0.10 & 32.0 \\
\hline & & Starting own family & 0.00 & 0.57 & 0.05 & 0.91 & 0.91 & 40.8 \\
\hline & & Childless adult & 0.00 & 0.99 & 0.01 & 0.80 & 0.09 & 27.2 \\
\hline
\end{tabular}

Note: Probabilities higher than 0.5 - that are considered when interpreting and naming the latent classes - are shaded with grey.

Source: Longitudinal data from the Hungarian Generations and Gender Survey (2001-2013), birth cohort 1981-1983, $n=1000$, author's calculation.

Only three classes remain at the age of $29-31: 32 \%$ are employed but otherwise live in child status, $41 \%$ have established their own family, and $27 \%$ are childless adults. There are no full-time students any more and the group of young people who are in transition between education and employment has also disappeared. Interestingly, one-third of respondents aged around 30 still live with their parents in child status: they do not have their own family, but they are employed. This group can be considered the "least adult", as they have assumed only two of the five roles that are usually associated with adulthood. "The most adult" groups include childless adults and young people with their own family. 
Members of the former group have assumed all adult roles but parenthood, while members of the latter class are the least likely to be employed (83\% of men and $45 \%$ of women work in this group, and many women are on maternity or parental leave).

Based on the previous theoretical and empirical literature, we included several other variables in the LCA models that were supposed to distinguish groups. However, we could not identify any latent classes that were associated with temporary, precarious conditions or reversed transitions. We found no groups dominated by unmarried unions, dissolved cohabiting partnerships or divorces, living apart together relationships, temporary or part-time jobs, living alone, living only temporarily away from the parental household or returning to the parental home. These situations are probably present in the lives of many young people for some time, but they involve only one aspect of their lives, they may only apply to certain social groups, or they may emerge at later ages. Nevertheless, "traditional" status variables were still useful for identifying temporary, inconsistent situations and the postponement of becoming an adult.

\section{Latent pathways of becoming adult}

In the second part of the analysis, we analyzed the typical transitions between the role sets formed for the four time periods, and again, LCA was used to form groups. We distinguished four different pathways to adulthood. In other words, there is no single pathway that every young person goes through - there are significant differences in timing, and not everyone goes through all the transitions. Figure 3 depicts the probability of taking on the five adult roles as a function of age in each pathway. The graphs show the typical age and rate at which young people in the study experienced different life events; however, the order of the events cannot be inferred from them.

Most young people are classified as "late family formation after prolonged education" (51\%, B). They leave the education system late, late enough to graduate, and most of them acquire employment. They leave the parental home relatively late ( $40 \%$ of them still live with their parents at around the age of 30 ), and they form their own families even later. At the age of $29-31$, only $20 \%$ of them have children.

Every fourth respondent is characterized by early employment but late family formation (24\%, A). They study for a shorter period, enter the labor market sooner, move away from their parents and start their own families sooner than 
the previous group. Groups A and B reach similar life situations by the age of 29-31 but differ in the timing of important transitions because of their differential pathways in schooling.

Figure 3: Conditional probabilities of different roles by age in the four typical latent pathways into adulthood in Hungary between 2001 and 2013

A) Early employment,

late family formation (23.7\%)

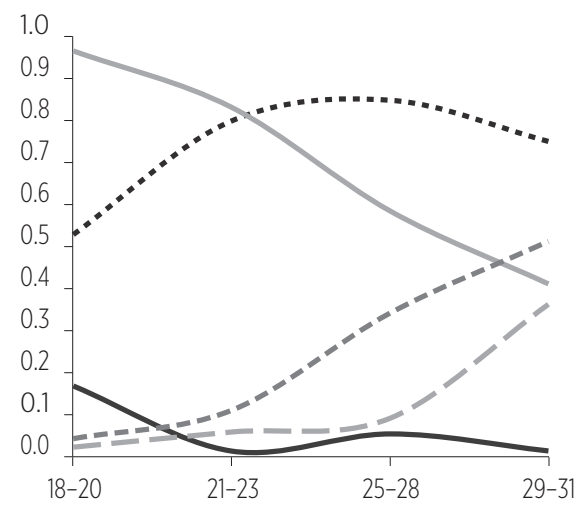

C) Early family formation (16.5\%)

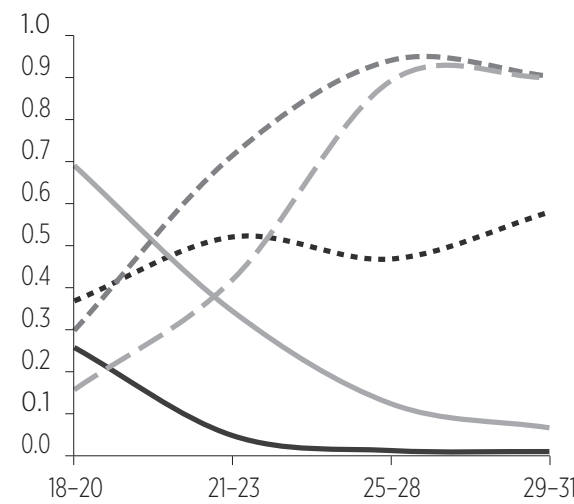

B) Late family formation after prolonged education (50.8\%)

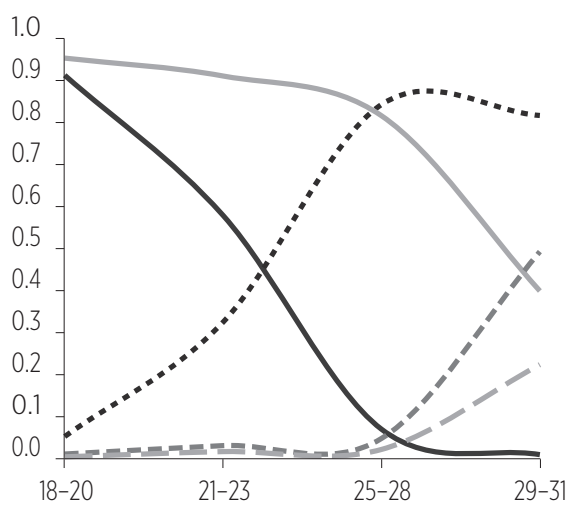

D) Rapid family formation after prolonged education (9.0\%)

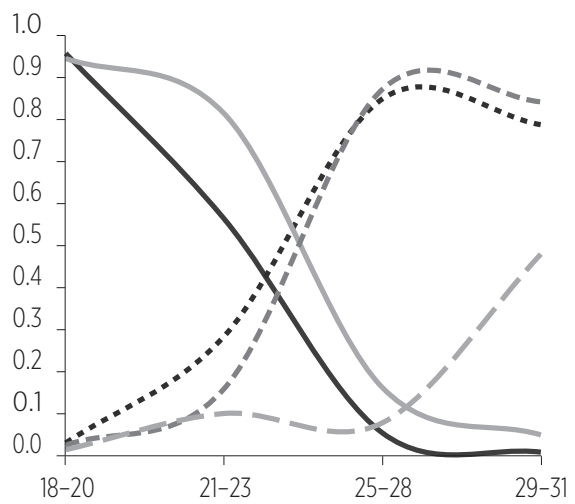

- Full-time student

....... Employed

_Lives with parents

---= Lives with partner/spouse

- - Has child(ren)

Source: Longitudinal data from the Hungarian Generations and Gender Survey (2001-2013), birth cohort 1981-1983, $n=1000$, author's calculation. 
$17 \%$ of young people are early family formers (C). They finish their studies early and move out of the parents' household, entering the labor market early. However, by the end of the observation period, they are the least likely to have employment (among women, this is partly due to childbearing). They form cohabitations or marry relatively early and at high rates, furthermore, 90\% have children by the age of 30 .

The smallest group (D) is named "rapid family formation after prolonged education" (9\%): their educational and labor market history is similar to that of the other educated group (B), but they leave their parents' household and start cohabitation or marriage earlier. Despite the early formation of partnerships, group D members have children relatively late. Members of group $D$ are the ones who follow the traditional pattern of transition to adulthood most closely, but it is also the group that is the smallest, both among women and men.

Figure 4: The distribution of women and men by pathways into adulthood in Hungary between 2001 and 2013

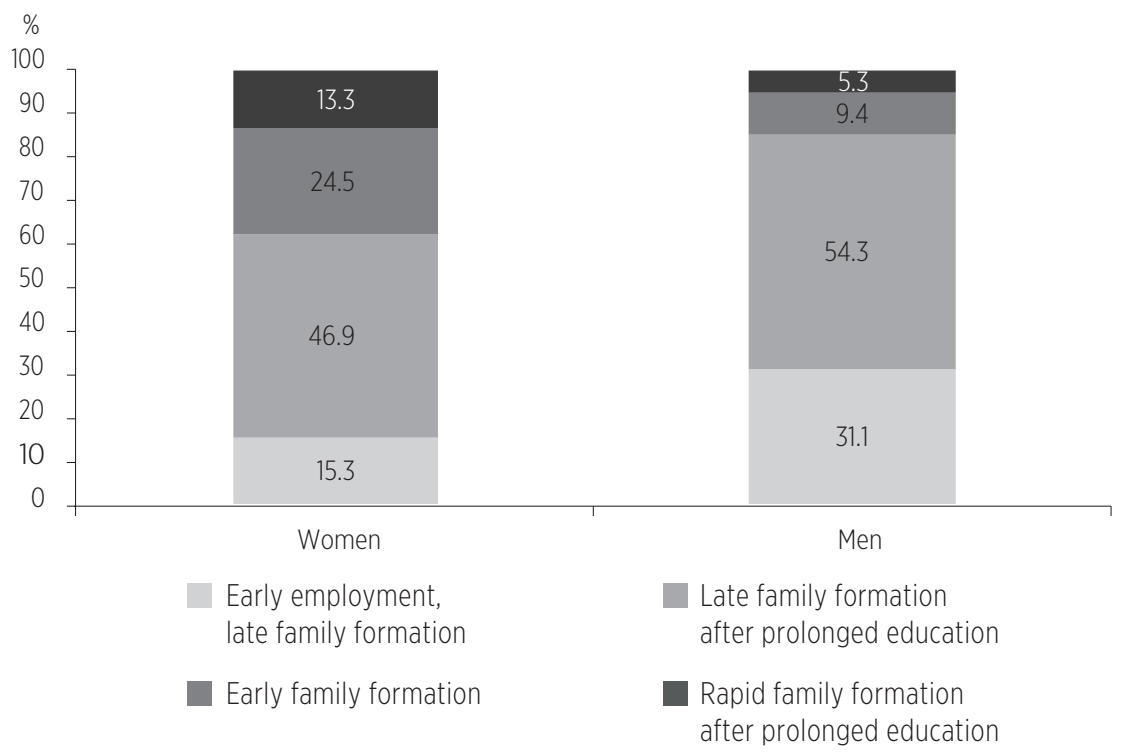

Note: The difference between men and women is statistically significant (based on Pearson's chi-squared test, $p=0.000$ ).

Source: Longitudinal data from the Hungarian Generations and Gender Survey (2001-2013), birth cohort 1981-1983, $n=1000$, author's calculation. 
There is a difference in the frequency of pathways to adulthood between women and men (Figure 4). Women are more likely than men to follow the standard, higher educated pathway, and it is the woman who predominantly from families early. One in two men are characterized by prolonged education and late family formation; this also being the most common pathway among women. Early employment and late family formation is a common pathway as well: every third man and only every seventh women fall under this category. Overall, an essential difference between men and women is that men are about four times more often form families late than women do.

\section{Family and social background of pathways to adulthood}

In the third part of the analysis, we illustrate whether the four pathways to adulthood differ in their background factors (Tables 3-5).

Two-thirds of respondents with early employment and late family formation are males. Children of parents with primary or vocational qualifications are over-represented, and so are skilled workers and village residents. This group has the lowest proportion of those who grew up in a two-parent family, although differences by childhood family composition are not statistically significant. From a financial point of view, they are slightly worse off than the average, with a high proportion of unemployed ( $27 \%$ of men, $15 \%$ of women), conscripts and other inactive groups. This group is also the least religious.

Two-thirds of early family formers are women, with the following groups overrepresented: those with low-educated parents, with two or more siblings, Roma and people living in the villages. Only about one-third of them work, one quarter are still studying, and many men are unemployed (25\%) or conscripted (13\%), and women are relatively often on parental leave (16\%) or other inactive (13\%). Their subjective household income is the lowest, and the rate of deprived is the highest among this group. One in ten members of the group suffers from some kind of health problem.

A relatively high proportion of members in the two educated groups have parents with secondary or tertiary education. In contrast, the number of siblings and the share of Roma ethnicity is the lowest in these two groups. Relatively many of them live in cities or towns and have favorable household income. In addition to the similarities, however, there are some essential differences between 
the two educated groups. Women are overrepresented in the pathway with rapid family formation after prolonged education, while the proportion of men and women is roughly balanced among members of the educated pathway with late family formation. Two-parent childhood family background is the most common in the educated group with rapid family formation, and this group is also the most religious. In the educated group with late family formation, more people study in secondary or higher vocational education and less in tertiary education than in the educated group with family. Among young people in the two groups with prolonged education, the financial situation of respondents who form their own family quickly after finishing school is also better than that of people who postpone family formation.

Table 3: Sex and family background at age 18-20 by pathways into adulthood in Hungary, 2001/2002

\begin{tabular}{|c|c|c|c|c|c|}
\hline & $\begin{array}{c}\text { Early } \\
\text { employ- } \\
\text { ment, late } \\
\text { family } \\
\text { formation }\end{array}$ & $\begin{array}{c}\text { Late } \\
\text { family } \\
\text { formation } \\
\text { after } \\
\text { prolonged } \\
\text { education }\end{array}$ & $\begin{array}{c}\text { Early } \\
\text { family } \\
\text { formation }\end{array}$ & $\begin{array}{c}\text { Rapid } \\
\text { family } \\
\text { formation } \\
\text { after } \\
\text { prolonged } \\
\text { education }\end{array}$ & Total \\
\hline \multicolumn{6}{|l|}{ Sex*** } \\
\hline Female & 30.2 & 43.2 & 69.7 & 69.0 & 46.8 \\
\hline Male & 69.8 & 56.8 & 30.3 & 31.0 & 53.2 \\
\hline \multicolumn{6}{|l|}{ Education of parents (if available) ${ }^{* * *}$} \\
\hline At most eight years of primary school & 19.4 & 5.7 & 25.6 & 5.2 & 12.3 \\
\hline Vocational school & 39.5 & 22.8 & 42.6 & 28.5 & 30.7 \\
\hline Secondary education & 33.0 & 40.9 & 21.0 & 39.6 & 35.5 \\
\hline Tertiary degree & 8.1 & 30.6 & 10.8 & 26.8 & 21.6 \\
\hline \multicolumn{6}{|l|}{ Family structure before the age of 16} \\
\hline $\begin{array}{l}\text { Lived with both biological parents the whole } \\
\text { time }\end{array}$ & 68.8 & 74.6 & 74.2 & 83.8 & 74.0 \\
\hline $\begin{array}{l}\text { Lived with only one biological parent for } \\
\text { some time }\end{array}$ & 16.9 & 11.9 & 11.7 & 3.6 & 12.3 \\
\hline $\begin{array}{l}\text { Lived with only one biological parent and } \\
\text { lived with step-parent for some time }\end{array}$ & 14.3 & 13.5 & 14.1 & 12.6 & 13.7 \\
\hline $\begin{array}{l}\text { Number of siblings the respondent grew up } \\
\text { with (mean)*** }\end{array}$ & 2.4 & 2.2 & 3.0 & 2.2 & 2.4 \\
\hline Roma ethnicity*** & 5.7 & 2.0 & 16.9 & 0.9 & 5.2 \\
\hline
\end{tabular}

Notes: ${ }^{* * *} p<0.001,{ }^{* *} p<0.01,{ }^{*} p<0.05,{ }^{\dagger} p<0.1$ (based on Pearson's chi-squared test and ANOVA).

Source: Longitudinal data from the Hungarian Generations and Gender Survey (2001-2013), birth cohort 1981-1983, $n=1000$, author's calculation. 
Table 4: Socio-economic status at age 18-20 by pathways into adulthood in Hungary, 2001/2002

$(\%)$

\begin{tabular}{|c|c|c|c|c|c|}
\hline & $\begin{array}{c}\text { Early } \\
\text { employ- } \\
\text { ment, late } \\
\text { family } \\
\text { formation }\end{array}$ & $\begin{array}{c}\text { Late } \\
\text { family } \\
\text { formation } \\
\text { after } \\
\text { prolonged } \\
\text { education }\end{array}$ & $\begin{array}{c}\text { Early } \\
\text { family } \\
\text { formation }\end{array}$ & $\begin{array}{l}\text { Rapid } \\
\text { family } \\
\text { formation } \\
\text { after } \\
\text { prolonged } \\
\text { education }\end{array}$ & Total \\
\hline \multicolumn{6}{|l|}{ Attended educational institution (if studying)*** } \\
\hline Primary school & 3.5 & 0.7 & 0.0 & 0.0 & 0.7 \\
\hline Vocational school & 0.0 & 10.4 & 23.0 & 7.8 & 10.5 \\
\hline Vocational secondary school & 18.9 & 23.1 & 17.4 & 19.8 & 22.0 \\
\hline General secondary school & 39.2 & 15.3 & 5.4 & 12.1 & 15.3 \\
\hline Higher vocational training school & 22.2 & 18.4 & 22.2 & 13.7 & 18.3 \\
\hline College & 16.3 & 19.6 & 25.3 & 24.5 & 20.5 \\
\hline University & 0.0 & 12.4 & 6.7 & 22.1 & 12.7 \\
\hline \multicolumn{6}{|l|}{$\begin{array}{l}\text { Highest level of completed education } \\
\text { (if not studying)*** }\end{array}$} \\
\hline At most eight years of primary school & 19.6 & - & 38.2 & - & 25.7 \\
\hline Vocational school & 46.1 & - & 47.0 & - & 44.2 \\
\hline Vocational secondary school & 25.6 & - & 9.8 & - & 20.7 \\
\hline General secondary school & 8.7 & - & 5.0 & - & 9.4 \\
\hline \multicolumn{6}{|l|}{ Labor market status*** } \\
\hline (Self-)employed & 56.3 & 2.8 & 36.1 & 1.1 & 20.8 \\
\hline Student & 0.8 & 95.4 & 24.9 & 98.2 & 61.6 \\
\hline On maternity or childcare leave & 2.6 & 0.0 & 11.7 & 0.0 & 2.5 \\
\hline Unemployed & 23.7 & 1.7 & 13.5 & 0.0 & 8.7 \\
\hline Military service & 6.9 & 0.0 & 4.0 & 0.0 & 2.3 \\
\hline Other inactive & 9.7 & 0.1 & 9.8 & 0.7 & 4.0 \\
\hline Material deprivation*** & 31.8 & 20.4 & 40.7 & 8.0 & 25.3 \\
\hline \multicolumn{6}{|l|}{ Subjective household income ${ }^{* *}$} \\
\hline Have to go without & 4.1 & 2.8 & 8.0 & 1.7 & 3.9 \\
\hline \multirow{3}{*}{$\begin{array}{l}\text { Financial problems from month to month } \\
\text { Can just make ends meet by budgeting } \\
\text { carefully } \\
\text { Live acceptably }\end{array}$} & 19.6 & 13.0 & 23.8 & 6.5 & 15.7 \\
\hline & 43.8 & 38.9 & 38.4 & 44.1 & 40.4 \\
\hline & 29.8 & 38.3 & 27.5 & 42.5 & 34.9 \\
\hline Live without problems & 2.8 & 7.0 & 2.2 & 5.2 & 5.1 \\
\hline \multicolumn{6}{|l|}{ Place of residence ${ }^{* * *}$} \\
\hline Budapest & 20.4 & 23.8 & 8.5 & 16.8 & 19.9 \\
\hline City & 13.0 & 24.2 & 20.7 & 26.8 & 21.2 \\
\hline Town & 28.4 & 25.9 & 27.9 & 29.8 & 27.2 \\
\hline Village & 38.2 & 26.0 & 42.9 & 26.6 & 31.7 \\
\hline
\end{tabular}

Notes: ${ }^{* * *} p<0.001,{ }^{* *} p<0.01,{ }^{*} p<0.05,{ }^{\dagger} p<0.1$ (based on Pearson's chi-squared test and ANOVA).

Source: Longitudinal data from the Hungarian Generations and Gender Survey (2001-2013), birth cohort 1981-1983, $n=1000$, author's calculation. 
Table 5: Health, wellbeing and values at age 18-20 by pathways into adulthood in Hungary, 2001/2002

\begin{tabular}{|c|c|c|c|c|c|}
\hline & $\begin{array}{l}\text { Early } \\
\text { employ- } \\
\text { ment, late } \\
\text { family } \\
\text { formation }\end{array}$ & $\begin{array}{c}\text { Late } \\
\text { family } \\
\text { formation } \\
\text { after } \\
\text { prolonged } \\
\text { education }\end{array}$ & $\begin{array}{c}\text { Early } \\
\text { family } \\
\text { formation }\end{array}$ & $\begin{array}{c}\text { Rapid } \\
\text { family } \\
\text { formation } \\
\text { after } \\
\text { prolonged } \\
\text { education }\end{array}$ & Total \\
\hline Limited by health problem* & 9.6 & 6.2 & 10.0 & 1.0 & 7.2 \\
\hline Loneliness (mean)* & 7.8 & 7.3 & 7.9 & 7.0 & 7.5 \\
\hline Life satisfaction (mean, $0-10)^{* * *}$ & 6.5 & 7.4 & 6.5 & 7.8 & 7.0 \\
\hline Religious ${ }^{+}$ & 49.7 & 56.1 & 61.5 & 68.9 & 56.7 \\
\hline
\end{tabular}

Notes: ${ }^{* * *} p<0.001,{ }^{* *} p<0.01,{ }^{*} p<0.05,{ }^{\dagger} p<0.1$ (based on Pearson's chi-squared test and ANOVA).

Source: Longitudinal data from the Hungarian Generations and Gender Survey (2001-2013), birth cohort 1981-1983, $n=1000$, author's calculation.

\section{Outcomes of pathways}

After examining backgrounds factors, we turn to the question of what characterizes respondents aged 29-31 who followed different pathways to adulthood (Tables 6-8).

Four-fifths of the "early employment, late family formation" group is unmarried. However, many have been cohabiting or living-apart-together, while one-third of them have already broken up a previous relationship or divorced their spouses. About half of the group's single members want to move in with a partner within the next three years. The number of children among group members is relatively low, but 55\% want a(n) (additional) child within the next three years. This group has the highest proportion of youth living with parents (53\%), and $12 \%$ of those who share a household with their parents also have a cohabiting partner or spouse. Although the proportion of singles is relatively high, due to frequent cohabitation with parents, only $9 \%$ live in a one-person household, which is no different from the sample average.

The members of the "early employment, late family formation" group have relatively low education compared to members of other groups (e.g. only 6\% have a college or university degree). Four-fifths of them work, although twothirds have been unemployed at least once in their lifetime (the highest rate among the four groups), and $13 \%$ are still unemployed. The employment rates of women and men do not differ significantly from each other, and the unemployment rate of $18 \%$ for men compares to the proportion of women on parental 
leave (also 18\%). The highest share of self-employed and skilled workers can be found in this group, while relatively few have non-manual occupations. The share of precarious work and their financial situation can be seen as average. Their health and well-being can also be considered average, but the proportion of smokers in this group is very high (40\%).

Table 6: Demographic status at age 29-31 by pathways into adulthood in Hungary, 2012/2013

\begin{tabular}{|c|c|c|c|c|c|}
\hline & $\begin{array}{c}\text { Early } \\
\text { employ- } \\
\text { ment, late } \\
\text { family } \\
\text { formation }\end{array}$ & $\begin{array}{c}\text { Late } \\
\text { family } \\
\text { formation } \\
\text { after } \\
\text { prolonged } \\
\text { education }\end{array}$ & $\begin{array}{c}\text { Early } \\
\text { family } \\
\text { formation }\end{array}$ & $\begin{array}{c}\text { Rapid } \\
\text { family } \\
\text { formation } \\
\text { after } \\
\text { prolonged } \\
\text { education }\end{array}$ & Total \\
\hline \multicolumn{6}{|l|}{ Marital status*** } \\
\hline Never married & 79.9 & 77.4 & 37.2 & 42.1 & 64.3 \\
\hline Married & 12.9 & 20.1 & 49.8 & 48.9 & 29.1 \\
\hline Divorced & 7.2 & 2.5 & 13.0 & 8.9 & 6.6 \\
\hline \multicolumn{6}{|l|}{ Partnership status ${ }^{* * *}$} \\
\hline Lives with partner or spouse & 42.5 & 45.8 & 88.3 & 95.3 & 61.2 \\
\hline Has a partner but they do not live together & 26.6 & 20.3 & 0.9 & 3.6 & 15.1 \\
\hline Has no partner & 30.9 & 34.2 & 10.8 & 1.1 & 23.7 \\
\hline $\begin{array}{l}\text { Ever experienced partnership dissolution or } \\
\text { divorce }^{* *}\end{array}$ & 31.8 & 21.3 & 44.0 & 37.7 & 30.7 \\
\hline \multicolumn{6}{|l|}{ Household type $\mathrm{e}^{* * *}$} \\
\hline Lives alone & 9.2 & 12.9 & 0.9 & 4.7 & 8.4 \\
\hline Single parent & 2.0 & 2.1 & 10.1 & 0.0 & 3.5 \\
\hline $\begin{array}{l}\text { Lives with own parent(s) (with no partner or } \\
\text { children) }\end{array}$ & 43.1 & 36.3 & 0.0 & 0.0 & 24.8 \\
\hline Single parent, lives with own parent(s) & 3.2 & 1.5 & 0.7 & 0.0 & 1.5 \\
\hline Couple with no children & 18.6 & 27.2 & 5.8 & 48.2 & 23.9 \\
\hline Couple with child(ren) & 17.9 & 13.5 & 81.5 & 45.9 & 33.6 \\
\hline Couple with parent(s) (with no children) & 3.4 & 2.6 & 0.0 & 1.3 & 2.0 \\
\hline Couple with child(ren) and parent(s) & 2.8 & 2.3 & 0.9 & 0.0 & 1.8 \\
\hline Other & 0.0 & 1.5 & 0.0 & 0.0 & 0.7 \\
\hline
\end{tabular}

Notes: ${ }^{* * *} p<0,001,{ }^{* *} p<0,01,{ }^{*} p<0,05,{ }^{\dagger} p<0,1$ (based on Pearson's chi-squared test and ANOVA).

Source: Longitudinal data from the Hungarian Generations and Gender Survey (2001-2013), birth cohort 1981-1983, $n=1000$, author's calculation.

The partnership and family situation of the group with late family formation after prolonged education at the age of 29-31 is similar to that of the group with early employment and late family formation, but there are some important dif- 
ferences. Members of the former group include slightly more married and single people, while the proportion of those who experienced partnership dissolution or divorce is below average. It is within this group that the share of people living in a one-person household is the highest (13\%), $43 \%$ live with their parents, out of whom $11 \%$ also have coresident partner. Among singles, $72 \%$ want to move in with a partner in the near future, and two-thirds of them would like to have a(n) (additional) child within the next three years.

Half of the members of the educated, late family former group have a tertiary degree and $90 \%$ have finished at least secondary education. Four-fifths of them are in paid employment ( $84 \%$ of men, $72 \%$ of women), they have an average rate of unemployed among them ( $6 \%$ of women, $12 \%$ of men), and $21 \%$ of women in this group are on parental leave. Most members of this pathway group are subordinate non-manual workers (45\%), managers (20\%) or skilled workers (21\%). Experience with insecure employment and unemployment are less typical among them than the average. Their financial situation is relatively favorable and their level of wellbeing is average.

The vast majority of early family formers live with a spouse or partner and only $11 \%$ are single. In contrast, many (44\%) have already broken up at least one longterm relationship, with $13 \%$ of them divorced and $11 \%$ of them being single parents. This group has the highest rate of single parents and the highest mean number of children. However, within the next three years, only $20 \%$ would like to have another child; thus, the childbearing phase is over for the majority of the group.

The group of early family formers have the lowest level of education: $23 \%$ have completed primary education at most and $41 \%$ completed vocational school. At the same time, 37\% have secondary or tertiary education, so it cannot be said that there are only low-educated people making up this group. The employment rate is the lowest within this group, mainly due to the relatively high proportion of group members on parental leave (27\% of women). $55 \%$ of early family formers were at some point already unemployed and $12 \%$ are still unemployed ( $22 \%$ of men and $8 \%$ of women). Low educational attainment is associated with a high proportion of manual workers and a low proportion of managers or intellectual workers. Job insecurity affects every third employee in the group, thus exceeding the sample average one and a half times. Subjective household income is the lowest in this group, while they have the highest rate of material deprivation: one in three households is deprived, with $44 \%$ having regular financial difficulties, or even in need of basic resources. The group is characterized by above-average levels of smoking, loneliness and dissatisfaction with life. 
Table 7: Socio-economic status at age 29-31 by pathways into adulthood in Hungary, 2012/2013

$(\%)$

\begin{tabular}{|c|c|c|c|c|c|}
\hline & $\begin{array}{l}\text { Early } \\
\text { employ- } \\
\text { ment, late } \\
\text { family } \\
\text { forma- } \\
\text { tion }\end{array}$ & $\begin{array}{l}\text { Late } \\
\text { family } \\
\text { formation } \\
\text { after } \\
\text { prolon- } \\
\text { ged edu- } \\
\text { cation }\end{array}$ & $\begin{array}{l}\text { Early } \\
\text { family } \\
\text { forma- } \\
\text { tion }\end{array}$ & $\begin{array}{c}\text { Rapid } \\
\text { family } \\
\text { formation } \\
\text { after } \\
\text { prolon- } \\
\text { ged edu- } \\
\text { cation }\end{array}$ & Total \\
\hline \multicolumn{6}{|l|}{ Education*** } \\
\hline At most eight years of primary school & 16.2 & 0.0 & 23.0 & 0.0 & 8.4 \\
\hline Vocational school & 44.8 & 10.3 & 40.5 & 14.6 & 24.7 \\
\hline Vocational secondary school & 16.1 & 20.1 & 14.5 & 14.9 & 17.3 \\
\hline General secondary school & 11.3 & 9.8 & 7.5 & 6.0 & 9.1 \\
\hline Higher vocational training school & 5.3 & 17.3 & 3.8 & 17.3 & 11.9 \\
\hline College, BA & 6.3 & 22.5 & 8.7 & 22.7 & 16.1 \\
\hline University, MA, PhD & 0.0 & 20.0 & 2.0 & 24.5 & 12.5 \\
\hline \multicolumn{6}{|l|}{ Labor market status** } \\
\hline (Self-)employed & 78.6 & 79.3 & 61.2 & 73.8 & 74.5 \\
\hline Student & 0.0 & 1.0 & 0.0 & 0.0 & 0.4 \\
\hline On maternity or childcare leave & 4.9 & 8.8 & 20.1 & 19.3 & 11.9 \\
\hline Unemployed & 12.9 & 9.6 & 11.9 & 5.8 & 10.3 \\
\hline Other inactive & 3.6 & 1.4 & 6.9 & 1.2 & 3.0 \\
\hline Unemployment experience*** & 69.5 & 41.5 & 54.6 & 33.1 & 49.0 \\
\hline \multicolumn{6}{|l|}{ Type of worker (if works) ${ }^{* * *}$} \\
\hline Self-employed & 11.2 & 4.4 & 3.3 & 0.0 & 5.1 \\
\hline Skilled worker & 32.7 & 20.8 & 27.6 & 5.5 & 22.5 \\
\hline Semi-skilled worker & 18.1 & 8.2 & 23.1 & 23.0 & 15.2 \\
\hline Unskilled worker & 9.0 & 0.7 & 9.8 & 0.0 & 4.1 \\
\hline Manager & 5.2 & 20.0 & 1.1 & 6.3 & 11.4 \\
\hline $\begin{array}{l}\text { Subordinate non-manual worker with tertiary } \\
\text { degree }\end{array}$ & 5.3 & 27.5 & 11.7 & 45.4 & 22.3 \\
\hline $\begin{array}{l}\text { Subordinate non-manual worker with secondary } \\
\text { degree }\end{array}$ & 11.6 & 15.8 & 13.3 & 15.1 & 14.3 \\
\hline Other non-manual worker & 5.4 & 1.3 & 3.9 & 0.0 & 2.5 \\
\hline Casual manual worker & 1.5 & 1.3 & 6.2 & 4.7 & 2.7 \\
\hline Unstable employment (if works)** & 22.7 & 15.9 & 36.4 & 11.9 & 20.5 \\
\hline Material deprivation ${ }^{* * *}$ & 12.7 & 10.6 & 31.0 & 17.8 & 15.1 \\
\hline \multicolumn{6}{|l|}{ Subjective household income*** } \\
\hline Have to go without & 4.9 & 4.8 & 8.1 & 0.0 & 4.8 \\
\hline Financial problems from month to month & 16.2 & 9.7 & 35.4 & 21.8 & 18.3 \\
\hline $\begin{array}{l}\text { Can just make ends meet by budgeting } \\
\text { carefully }\end{array}$ & 46.1 & 41.7 & 42.5 & 30.1 & 41.1 \\
\hline Live acceptably & 31.6 & 37.1 & 14.0 & 35.2 & 30.7 \\
\hline Live without problems & 1.3 & 6.8 & 0.0 & 13.0 & 5.1 \\
\hline
\end{tabular}

Notes: ${ }^{* * *} p<0.001,{ }^{* *} p<0.01,{ }^{*} p<0.05,{ }^{\dagger} p<0.1$ (based on Pearson's chi-squared test).

Source: Longitudinal data from the Hungarian Generations and Gender Survey (2001-2013), birth cohort 1981-1983, $n=1000$, author's calculation. 
Table 8: Health, wellbeing, intentions and values at age 29-31 by pathways into adulthood in Hungary, 2012/2013

(\%)

\begin{tabular}{|c|c|c|c|c|c|}
\hline & $\begin{array}{c}\text { Early } \\
\text { employ- } \\
\text { ment, late } \\
\text { family } \\
\text { formation }\end{array}$ & $\begin{array}{c}\text { Late } \\
\text { family } \\
\text { formation } \\
\text { after } \\
\text { prolonged } \\
\text { education }\end{array}$ & $\begin{array}{c}\text { Early } \\
\text { family } \\
\text { formation }\end{array}$ & $\begin{array}{c}\text { Rapid } \\
\text { family } \\
\text { formation } \\
\text { after } \\
\text { prolonged } \\
\text { education }\end{array}$ & Total \\
\hline \multicolumn{6}{|l|}{ Health, wellbeing } \\
\hline Limited by health problem & 5.6 & 6.1 & 7.6 & - & 5.4 \\
\hline Loneliness (mean)** & 7.0 & 7.1 & 7.8 & 6.0 & 7.1 \\
\hline Life satisfaction (mean, $0-10)^{*}$ & 7.0 & 7.4 & 6.7 & 7.6 & 7.2 \\
\hline Smoking ${ }^{* * *}$ & 40.2 & 29.7 & 38.9 & 13.7 & 31.6 \\
\hline \multicolumn{6}{|l|}{ Intentions, values } \\
\hline $\begin{array}{l}\text { Intention to start living with a partner within } \\
\text { three years (if has no partner or spouse) }{ }^{\dagger}\end{array}$ & 56.4 & 71.9 & 57.5 & - & 66.6 \\
\hline Intention to have children within three years ${ }^{* * *}$ & 54.8 & 65.7 & 20.1 & 72.4 & 54.6 \\
\hline Religious $* * *$ & 57.1 & 57.3 & 66.9 & 79.2 & 62.5 \\
\hline
\end{tabular}

Notes: "-": the cell has low number of cases; ${ }^{* * *} p<0.001,{ }^{* *} p<0.01,{ }^{*} p<0.05,{ }^{\dagger} p<0.1$ (based on Pearson's chi-squared test and ANOVA).

Source: Longitudinal data from the Hungarian Generations and Gender Survey (2001-2013), birth cohort 1981-1983, $n=1000$, author's calculation.

Almost every young people who have followed the "rapid family formation after prolonged education" pathway live with a spouse or a partner (95\%). Their mean number of children is just over one and half of the couples are (still) childless. For many, the childbearing period is not over or has not begun, indicated by the fact that $70 \%$ of them want a (new) child within the next three years. Those who do not have a cohabiting partner usually live alone; cohabitation with parents is not typical within this group.

$86 \%$ of the educated group with rapid family formation have completed at least secondary education and $47 \%$ are college or university graduates. Two thirds (68\% of women and $93 \%$ of men) are employed, while a quarter of women are on parental leave. Unemployment rates are low, and they have experienced the lowest rates of unemployment at any point in their life (33\%). Two-thirds of them do non-manual work, but the proportion of unskilled workers is also surprisingly high (which may be a random effect due to the small number of people making up this group within the sample). They are less characterized by job insecurity and material deprivation, and subjective household income is the highest in this group. They are also the most religious group, the most satisfied with their lives, the least lonely, and only $14 \%$ of group members smoke. 


\section{CONCLUSIONS}

We analyzed the process of the transition to adulthood, the background and outcomes of different pathways of young people in the early 2000s in Hungary. We used longitudinal data from the Hungarian Generations and Gender Survey on the life course of the 1981-1983 birth cohort between the ages of 18 and 31. We applied the method of two-step latent class analysis.

Our results suggest that the life situation of young people shows great variety during their twenties and also differs by age. The transitory period between adolescence and adulthood - postadolescence - can be characterized by quite different role configurations, and it is not a uniform phase of the life course. The empirical analysis identified four different pathways into adulthood; thus there is no single dominant pathway. The most common type is characterized by prolonged education and delayed family formation (51\%). Every fourth young person become employed early and form their own family late; $17 \%$ establish a family early. Interestingly, the pathway that resembles the traditional, linear model of transition to adulthood the most (rapid family formation after prolonged education) is the least frequent (9\%).

Identified pathways show strong resemblance to results from other countries (e.g. United States, United Kingdom, Finland) from analyses using similar methods (Amato et al., 2008; Osgood et al., 2005; Räikkönen et al., 2012; Schoon, 2014), which is surprising in light of the cultural, social and economic differences between these countries. The pathways identified in international comparisons (which included Hungarian data) are also partially consistent with the groups we have found (Lesnard et al., 2016; Schwanitz, 2017). Each of the cited studies found a relatively populous, educated, childless group, independent from parents, which corresponds to our "late family formation after prolonged education" pathway. The largest group identified by international research is work-oriented, childless and typically holds secondary educational qualifications. Often there is also a similar "belated" group, except that many of its members still live in their parents' household. These two pathways correspond to the "early employment, late family formation" group in our analysis. There is also a "vulnerable" group in the UK who are low-educated, rarely employed and form families early, which is in line with our "early family formation" pathway.

Those who follow more conventional patterns of family life course, according to international results, have assumed every adult role by the second half of their twenties, and generally have low or secondary education. In the Hungarian context, however, this pathway is more typical of the educated (and those with the 
most advantageous family background), and they are the ones who reach the most favorable positions by their early thirties. Thus, it is a Hungarian peculiarity that the most standard - and rarest - pathway to adulthood is a kind of "social privilege". During a relatively long period of studying, they can take advantage of a prolonged process of the transition to adulthood, improve their human capital while still relying on parental resources. They can gain favorable employment and a good financial position relatively soon after leaving school, and they do not delay (any further) leaving the parental household, starting to live with a partner or getting married.

Thus, the results confirm that not only the journey itself (the timing of certain role transitions in reaching adult status) is different for young people on different pathways to adulthood, but their position at the beginning and, of course, at the end of the journey can also be quite different. However, alongside divergence, pathways remain more or less structurally defined. The time spent in the educational system structures young people's life course: fulltime employment and hence financial independence can only be achieved after completing full-time studies, and family formation is delayed as a result of it due to incompatibilities between student and family roles (Blossfeld and Huinink, 1991; Molnár, 2014; Spéder and Bartus, 2016). Naturally, the difference in pathways for people with lower and higher levels of education is not only due to the fact that they graduate at different ages, but the education they obtain strongly influences other dimensions of their lives, for example, their labor market and family trajectories.

According to our findings on socio-economic differences, the background and the achieved position of the two educated groups are the most favorable. They enter employment after a relatively long educational period at similar ages. They differ most in the timing of family formation and educated people with rapid family formation tend to be more religious. The situation of early employment seekers and late family formers is worse than the average, but their labor market position is better than that of early family formers. They are often characterized by broken relationships, joint households with parents, and unemployment experience. They reach adult status in certain dimensions relatively early and quite late in other aspects.

There are two pathways characterized by late family formation: one with early employment and lower level of education, and one with prolonged education. By the age of 30, just over half of the members of the former group and $72 \%$ of the latter group would like to live together with a partner within the next three years. We can find a similar difference in the intention to have a child within the 
next three years (55 vs. 66\%). This implies that about half of low-educated childless singles in the "early employment, late family formation" group have no relationship or childbearing plans (which may be related to a previous partnership dissolution or they may have abandoned their family formation plans because they are less "marketable" in the relationship market). The more educated most often show a timing effect: after lengthy studies, they have had a shorter time to establish a lasting relationship, and many have not abandoned their childbearing and family plans around the age of 30 .

The background and outcomes of the early family formers are the most disadvantaged. The primary way for them to reach adult status is through early partnerships and childbearing, and their labor market integration is rather low. Parental resources are relatively scarce and hard to access, and the socio-economic disadvantages of their parents are often reproduced among them. There are three possible explanations for the relationship between disadvantage and early family formation. The first is that some of the early family formers have no other means available to become respected and recognized members of adult society (see Durst, 2006; Fernández-Kelly, 1995). Although disadvantaged social groups are overrepresented in this group, there are a good number of early family formers who do not share this background. In their case, there might be some kind of value selection at play (e.g. religiousness is the highest in this group). Besides, in a position characterized by feelings of insecurity and limited labor market opportunities - which does not necessarily imply objectively poor living conditions - partnership and parenthood can function as a stable point of reference (theory of the reduction of uncertainty; see Friedman et al., 1994; Bukodi and Róbert, 2005 made similar conclusions).

Concerning the relationship between the length of the postadolescent period and socio-economic status, the results support the finding cited earlier that both premature independence and "stalling" may be associated with social disadvantages (Arnett, 2000; Elder, 1975; Furstenberg, 2008; Furstenberg et al., 2004; Lui et al., 2014; Mortimer 2012). Rapid achievement of independence characterizes the by-now standard pathway of transition to adulthood after a relatively long time spent in education. It is most accessible to those with the most favorable childhood family background and it results in the more favorable outcomes at the age of 30.

Regarding the theoretical considerations that we discussed earlier, the "extended transition" model of Galland (2004: 151) can be modified to fit the contemporary Hungarian situation (Figure 4). The distinction between the pre-adult and the adult stage have become more blurred. The role transitions in the private sphere (family) and the public sphere (employment) are less synchronized than 
in the original model: the relative timing of the important life course transitions shows considerable variability. After the end of studies, there is a possible period of labor market precarity, followed by working life or inactivity (leaving the labor market). Some young people live with their parents for a long time - they either never leave or return to the parental home -, and this is linked not only to their family trajectory but also to their position in (or out of) the labor market. An additional difference from the original model is that in Hungary, there is no separate phase when young people typically live alone. Childbearing has been added to the model because it can be a means of gaining adult status. For many young people, however, parenthood and transition to adulthood are unrelated - the first child is born late and childlessness increases -, this is why childbearing is in parentheses in the model.

Figure 5: The modified "extended transition" model of transition to adulthood

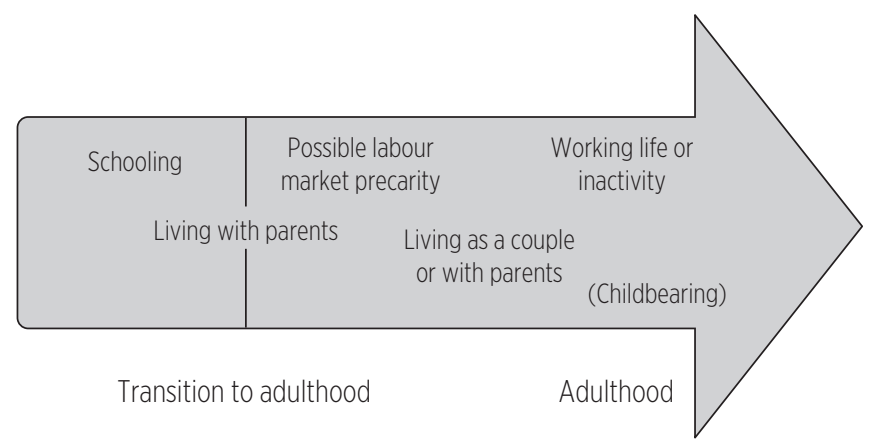

Note: The model is based on Galland (2004, p. 151) and has been adapted to the Hungarian situation by the author. 


\section{REFERENCES}

Ahmed, P. and Emigh, R. J. (2005). Household composition in post-socialist Eastern Europe. International Journal of Sociology and Social Policy, 25(3), pp. 9-41.

Amato, P. R., Landale, N. S., Havasevich, T. C., Booth, A., Eggebeen, D. J., Schoen, R. and McHale, S. M. (2008). Precursors of young women's family formation pathways. Journal of Marriage and Family, 70(5), pp. 1271-1286.

Arnett, J. J. (2000). Emerging adulthood: A theory of development from the late teens through the twenties. American Psychologist, 55(5), pp. 469-480.

Barban, N., and Billari, F. C. (2012). Classifying life course trajectories: A comparison of latent class and sequence analysis. Journal of the Royal Statistical Society: Series C (Applied Statistics), 61(5), pp. 765-784.

Bauer B. and Szabó A. (eds.) (2005). Ifjúság2004: Gyorsjelentés [Youth2004: Flash Report]. Budapest: Mobilitás Ifjúságkutatási Iroda.

Beck, U. and Beck-Gernsheim, E. (2002). Individualization: Institutionalized individualism and its social and political consequences. Thousand Oaks: Sage.

Bene V., Krémer B. and Pintye Zs. (2018). A 15-29 éves korosztály foglalkoztatásáról és munkaerőpiaci perspektíváiról a Magyar Ifjúság Kutatás 2016 adatainak tükrében [On the employment and labor market perspectives of the 15-29 age group in light of the Hungarian Youth Study 2016]. In Nagy Á., ed., Margón kivül: Magyar ifjúságkutatás 2016. Budapest: Excenter Kutatóközpont, pp. 98-153.

Billari, F. C. (2001). The analysis of early life courses: Complex descriptions of the transition to adulthood. Journal of Population Research, 18(2), pp. 119-142.

Billari, F. C., Hiekel, N. and Liefbroer, A. C. (2019). The social stratification of choice in the transition to adulthood. European Sociological Review, 35(5), pp. 599-615.

Billari, F. C. and Liefbroer, A. C. (2010). Towards a new pattern of the transition to adulthood? Advances in Life Course Research, 15(2-3), pp. 59-75.

Blossfeld, H.-P. and Huinink, J. (1991). Human capital investments or norms of role transitions? How women's schooling and career affect the process of family formation. American Journal of Sociology, 97(1), pp. 143-168.

Bognár V. (2007). Első elszakadás a szülői háztól: A felnőtté válás kezdete? [Leaving the parental home for the first time: The beginning of transition to adulthood?] In Somlai P., ed., Új ifjúság: Szociológiai tanulmányok a posztadolescensekröl. Budapest: Napvilág, pp. 45-80.

Brückner, H. and Mayer, K. U. (2005). De-standardization of the life course: What it might mean? And if it means anything, whether it actually took place? Advances in Life Course Research, 9, pp. 27-53.

Bukodi, E. and Róbert, P. (2005). The effect of the globalization process on the transition to adulthood in Hungary. In H.-P. Blossfeld, E. Klijzing, M. Mills and K. Kurz, eds., Globalization, uncertainty and youth in society. London, New York: Routledge, pp. 177-213.

Collins, L. M. and Lanza, S. T. (2010). Latent class and latent transition analysis with applications in the social, behavioral, and health sciences. Hoboken: Wiley. 
Côtè, J. E. (2000). Arrested adulthood: The changing nature of maturity and identity. New York: New York University Press.

Côtè, J. E. and Bynner, J. (2008). Changes in the transition to adulthood in the UK and Canada: The role of structure and agency in emerging adulthood. Journal of Youth Studies, 11(3), pp. 251-268.

De Jong Gierveld, J., De Valk, H. and Blommesteijn, M. (2002). Living arrangements of older persons and family support in more developed countries. Population Bulletin of the United Nations, 42-43, pp. 193-217.

Domokos T. (2010). A felnőtt korba való átmenet demográfiája a poszt-szocialista Magyarországon [The demography of the transition to adulthood in post-socialist Hungary]. Új ifjúsági szem/e, 8(3), pp. 64-84.

D’Souza, J. (2017, June 28). Xennials, the microgeneration between Gen X and Millennials. Because you can be a bit of both. Huffington Post. Available from www.huffingtonpost.ca

Durst J. (2006). Kirekesztettség és gyermekvállalás. A romák termékenységének változása néhány „gettósodó” aprófaluban (1970-2004) [Exclusion and childbearing. Fertility changes among the Roma population in some small "ghetto-like" villages] (PhD dissertation, Budapesti Corvinus Egyetem, Szociológia Doktori Iskola). Downloaded from http://phd.lib.uni-corvinus.hu/24/

Easterlin, R. A. (1987). Birth and fortune: The impact of numbers on personal welfare (2nd ed). Chicago: University of Chicago Press.

Elder, G. H. (1975). Age differentiation and the life course. Annual Review of Sociology, 1(1), pp. 165-190.

Elder, G. H. (1985). Life course dynamics: Trajectories and transitions, 1968-1980. Ithaca, NY: Cornell University Press.

Elzinga, C. H. and Liefbroer, A. C. (2007). De-standardization of family-life trajectories of young adults: A cross-national comparison using sequence analysis. European Journal of Population, 23(3-4), pp. 225-250.

Fernández-Kelly, M. P. (1995). Social and cultural capital in the urban ghetto: Implications for the economic sociology of immigration. In A. Portes, ed., The economic sociology of immigration. Essays on networks, ethnicity, and entrepreneurship. New York: Sage, pp. 213-247.

Friedman, D., Hechter, M. and Kanazawa, S. (1994). A theory of the value of children. Demography, 31(3), pp. 375-401.

Furstenberg, F. F. (2008). The intersections of social class and the transition to adulthood. New Directions for Child and Adolescent Development, 119, pp. 1-10.

Furstenberg, F. F., Kennedy, S., McLoyd, V. C., Rumbaut, R. G. and Settersten, R. A. (2003). Between adolescence and adulthood: Expectations about the timing of adulthood. Network on the Transitions to Adulthood, Research Network Working Paper 1.

Furstenberg, F. F., Kennedy, S., McLoyd, V. C., Rumbaut, R. G. and Settersten, R. A. (2004). Growing up is harder to do. Contexts, 3(3), pp. 33-41.

Gábor K. (2000). A középosztály szigete [The island of the middle class]. Szeged: Belvedere Meridionale.

Galland, O. (2004). Sociologie de la jeunesse. Paris: Armand Colin. 
Gazsó F. and Laki L. (2004). Fiatalok az újkapitalizmusban [Youth in new capitalism]. Budapest: Napvilág.

Gazsó T. (2013). Munkaerő-piaci helyzetkép [Labor market report]. In Székely L., ed., Magyar ifjúság 2012. Tanulmánykötet. Budapest: Kutatópont, pp. 127-151.

George, L. K. (1993). Sociological perspectives in life transitions. Annual Review of Sociology, 19(1), pp. 353-373.

Hagenaars, J. A. and McCutcheon, A. L., eds. (2002). Applied latent class analysis. Cambridge: Cambridge University Press.

Herms-Bohnhoff, E. (1993). Hotel Mama: Warum erwachsene Kinder heute nicht mehr ausziehen. Zürich, Stuttgart: Kreuz Verlag.

Híves T. and Kozma T. (2014). Az expanzió vége? [The end of expansion?] Educatio, 2, pp. 239-252.

Hogan, D. P. and Astone, N. M. (1986). The transition to adulthood. American Review of Sociology, 12(1), pp. 109-130.

Kabai I., Kenéz A. and Iharos T., eds. (2018). Hol tartma a „társadalomtagozódás” vizsgálata? A ZSKE Társadalomtudományi Kutatóközpontjának elméleti és empirikus kisérleteiröl [What is the current status of research on social stratification? On the theoretical and empirical experiments of the KSU Research Center for Social Sciences]. Budapest: Zsigmond Király Egyetem, Ifjúságszakmai Társaság Alapítvány, L’Harmattan.

Kapitány B. (2006). Objektiv és szubjektiv tényezők a felnőtté válás átalakuló folyamatában [Objective and subjective factors during the changing process of the transition to adulthood]. Presented at Andorka Rudolf Emlékkonferencia, Budapest.

Keniston, K. (1968). Young radicals. New York: Harcourt, Brace \& World.

Klein, H. (1990). Adolescence, youth and young adulthood. Youth and Society, 21(4), pp. 446-471.

Kozma, T. (2010). Expanzió: Tények és előrejelzések, 1983-2020 [Expansion: Facts and projections, 1983-2020]. Educatio, 1, pp. 7-18.

Központi Statisztikai Hivatal (2005). Lakásviszonyok az ezredfordulón [Housing conditions at the turn of the century]. Budapest: Központi Statisztikai Hivatal.

Központi Statisztikai Hivatal (2012). Lakáshelyzet [Housing conditions]. In Társadalmi helyzetkép 2010. Budapest: Központi Statisztikai Hivatal.

Központi Statisztikai Hivatal (2016). Demográfiai évkönyv 2015 [Demographic yearbook 2015]. Budapest: Központi Statisztikai Hivatal.

Laki L. (2006). Az ifjúság a magyar társadalomban [Youth in Hungarian society]. In Kovách I., ed., Társadalmi metszetek: Érdekek és hatalmi viszonyok, individualizáció és egyenlötlenség a mai Magyarországon. Budapest: Napvilág, pp. 177-205.

Lanza, S. T., Dziak, J. J., Huang, L., Wagner, A. T. and Collins, L. M. (2018). LCA Stata plugin users' guide (Version 1.2.1). University Park, PA: Pennsylvania State University, The Methodology Center.

Lesnard, L., Cousteaux, A.-S., Chanvril, F. and Le Hay, V. (2016). Do transitions to adulthood converge in Europe? An optimal matching analysis of work-family trajectories of men and women from 20 European countries. European Sociological Review, 32(3), pp. 355-369. 
Liefbroer, A. C. (1999). From youth to adulthood: Understanding changing patterns of family formation from a life course perspective. In L. J. G. van Wissen and P. A. Dykstra, eds., Population issues: An interdisciplinary focus. New York: Kluwer, pp. 53-85.

Lui, C. K., Chung, P. J., Wallace, S. P. and Aneshensel, C. S. (2014). Social status attainment during the transition to adulthood. Journal of Youth and Adolescence, 43(7), pp. 11341150.

Macmillan, R. and Billari, F. C. (2012, May). Stability and change in the transition to adulthood: Latent structure analysis of three generations in the national longitudinal surveys. Paper prepared for submission to the 2012 Annual Meeting of the Population Association of America. Available from https://paa2012.princeton.edu

Macmillan, R. and Copher, R. (2005). Families in the life course: Interdependency of roles, role configurations, and pathways. Journal of Marriage and Family, 67(4), pp. 858-879.

Macmillan, R. and Eliason, S. R. (2003). Characterising the life course as role configurations and pathways: A latent structure approach. In J. T. Mortimer and M. J. Shanahan, eds., Handbook of the life course. New York: Kluwer Academic, Plenum Publishers, pp. 529-554.

Macura, M. and Mochizuki-Sternberg, Y. (1999). Fertility decline in the transition economies, 1982-1997: Political, economic and social factors. In United Nations Economic Commission for Europe, Economic Survey of Europe. New York: United Nations Economic Commission for Europe, pp. 181-194.

Magidson, J. and Vermunt, J. K. (2002). Latent class models for clustering: A comparison with K-means. Canadian Journal of Marketing Research, 20(1), pp. 37-44.

Manzoni, A. (2016). Conceptualizing and measuring youth independence multidimensionally in the United States. Acta Sociologica, 59(4), pp. 362-377.

Medgyesi M. and Nagy I. (2014). Fiatalok életkörülményei Magyarországon és az EU országaiban 2007 és 2012 között [Life circumstances of the youth in Hungary and the EU countries between 2007 and 2012]. In Kolosi T. and Tóth I. Gy., eds., Társadalmi Riport 2014. Budapest: TÁRKI, pp. 303-323.

Mills, M. and Blossfeld, H.-P. (2003). Globalization, uncertainty and changes in early life courses. Zeitschrift für Erziehungswissenschaft, 6(2), pp. 188-218.

Modell, J., Furstenberg, F. F. and Herschberg, T. (1976). Social change and transitions to adulthood in historical perspective. Journal of Family History, 1(1), pp. 7-32.

Molnár É. (2014). A kapunyitási pánik jelenségének vizsgálata a debreceni egyetemisták körében [Examining the phenomenon of quarter life crisis among students in Debrecen]. Metszetek, 3(1), 358-371.

Monostori J. and Murinkó L. (2019). Household and family structure. In Monostori J., Öri P. and Spéder Zs., eds., Demographic portrait of Hungary 2018: Report on the conditions of the Hungarian population. Budapest: Hungarian Demographic Research Institute, pp. 179-199.

Mortimer, J. T. (2012). Transition to adulthood, parental support, and early adult wellbeing: Recent findings from the Youth Development Study. In A. Booth, S. L. Brown, N. S. Landale, W. D. Manning and S. M. McHale, eds., Early adulthood in a family context. New York: Springer, pp. 27-34. 
Murinkó L. (2009). Elköltözés a szülői házból [Leaving the parental home]. In Spéder Zs. (ed.), Párhuzamok: Anyaországi és erdélyi magyarok a századfordulón (KSH Népességtudományi Kutatóintézet Kutatási Jelentések 86). Budapest: KSH Népességtudományi Kutatóintézet, pp. 107-131.

Murinkó L. (2010). Mitől lesz valaki felnőtt? A családi szerepek és az önállóvá válás szerepe a felnőttség megítélésében Magyarországon [What makes someone adult? The role of family transitions and independence in opinions about becoming adult]. Demográfia, 53(1), pp. 7-37.

Murinkó L. and Spéder Zs. (eds.) (2016). Felhasználói kézikönyv az Életünk fordulópontjai panelkutatás 1-4. hullámához [User guide to waves 1-4 of the Turning Points of the Life Course panel survey] (KSH Népességtudományi Kutatóintézet Kutatási Jelentések 97). Budapest: KSH Népességtudományi Kutatóintézet.

Nyüsti Sz. (2013). Oktatási helyzetkép [Education report]. In Székely L., ed., Magyar ifjúság 2012. Tanulmánykötet. Budapest: Kutatópont, pp. 90-125.

Oesterle, S., Hawkins, J. D., Hill, K. G. and Bailey, J. A. (2010). Men's and women's pathways to adulthood and their adolescent precursors. Journal of Marriage and Family, 72(5), pp. 1436-1453.

Organisation for Economic Co-operation and Development (2000). Education at a glance 2000: OECD indicators. Paris: OECD Publishing.

Organisation for Economic Co-operation and Development (2010). Education at a glance 2010: OECD indicators. Paris: OECD Publishing.

Osgood, D. W., Ruth, G., Eccles, J. S., Jacobs, J. E. and Barber, B. L. (2005). Six paths to adulthood: Fast starters, parents without careers, educated partners, educated singles, working singles, and slow starters. In R. A. Settersten, F. F. Furstenberg and R. Rumbaut, eds., On the frontier of adulthood: Theory, research, and public policy. Chicago: University of Chicago Press, pp. 320-355.

Räikkönen, E., Kokko, K., Chen, M. and Pulkkinen, L. (2012). Patterns of adult roles, their antecedents and psychosocial wellbeing correlates among Finns born in 1959. Longitudinal and Life Course Studies, 3(2), pp. 211-227.

Robbins, A. and Wilner, A. (2001). Quarterlife crisis: The unique challenges of life in your twenties. New York: Penguin Putnam.

Robette, N. (2010). The diversity of pathways to adulthood in France: Evidence from a holistic approach. Advances in Life Course Research, 15(2-3), pp. 89-96.

Ságvári, B. (2011). A net-generáció törésvonalai - kultúrafogyasztás és életstíluscsoportok a magyar fiatalok körében [Fractures within the Internet generation cultural consumption and lifestyle groups among Hungarian youth]. In Bauer B. and Szabó A., eds., Arctalan (?) nemzedék: Ifjúság 2000-2010. Budapest: Nemzeti Családés Szociálpolitikai Intézet, pp. 263-281.

Salmela-Aro, K., Kiuru, N., Nurmi, J.-E. and Eerola, M. (2014). Antecedents and consequences of transitional pathways to adulthood among university students: 18year longitudinal study. Journal of Adult Development, 21(1), pp. 48-58.

Schoon, I. (2015). Diverse pathways: Rethinking the transition to adulthood. In P. R. Amato, A. Booth, S. M. McHale and J. Van Hook, eds., Families in an era of increasing inequality: Diverging destinies. Zürich: Springer, pp. 115-136. 
Schwanitz, K. (2017). The transition to adulthood and pathways out of the parental home: A cross-national analysis. Advances in Life Course Research, 32, pp. 21-34.

Settersten, R. A. (2006). Becoming adult: Meanings and markers for young Americans. Network on the Transitions to Adulthood Working Paper, March.

Shanahan, M. J. (2000). Pathways to adulthood in changing societies: Variability and mechanisms in life course perspective. Annual Review of Sociology, 26(1), pp. 667692.

Shanahan, M. J., Porfeli, E. J., Mortimer, J. T. and Erickson, L. D. (2005). Subjective age identity and the transition to adulthood. When do adolescents become adults? In R. A. Settersten, F. F. Furstenberg and R. Rumbaut, eds., On the frontier of adulthood: Theory, research, and public policy. Chicago: University of Chicago Press, pp. 225-255.

Skogbrott Birkeland, M., Leversen, I., Torsheim, T. and Wold, B. (2014). Pathways to adulthood and their precursors and outcomes. Scandinavian Journal of Psychology, 55(1), pp. 26-32.

Somlai P. (2007). A posztadolescensek kora: Bevezetés [Era of postadolescence: Introduction]. In Somlai P., ed., Új Ifjúság: Szociológiai tanulmányok a posztadolescensekről. Budapest: Napvilág, pp. 9-43.

Somlai P. (2010). Változó ifjúság [Changing youth]. Educatio, 19(2), pp. 175-190.

Spéder Zs. (2007). The diversity of family structure in Europe: A survey on partnership, parenting and childhood across Europe around the millennium. Demográfia English Edition, 50(5), 105-134.

Spéder, Zs. and Bartus, T. (2016). Educational enrolment, double-status positions and the transition to motherhood in Hungary. European Journal of Population, 33(1), pp. 55-85.

Spéder, Zs., Kapitány, B. and Neumann, L. (2009). Life-course transitions in Hungary before and after the societal transformation. In D. Anxo, G. Bosch and J. Rubery, eds., The welfare state and life transitions: A European perspective. Cheltenham: Edward Eldgar, pp. 287-327.

Szabó A. and Bauer B., eds. (2009). Ifjúság2008. Gyorsjelentés [Youth2008. Flash report]. Budapest: Szociálpolitikai és Munkaügyi Intézet.

Szabó A., Bauer B. and Laki L. (2002). Ifjúság 2000. Tanulmányok I [Youth 2000. Studies 1]. Budapest: Nemzeti Ifjúságkutató Intézet.

Székely L., ed. (2013). Magyar ifjúság 2012. Tanulmánykötet [Hungarian youth 2012. Studies]. Budapest: Kutatópont.

Székely L. and Szabó A., eds. (2016). Magyar ifjúság kutatás 2016. Az ifjúságkutatás első eredményei. Ezek a mai fiatalok! [Hungarian youth study 2016. First results of the youth study. Kids these days!] Budapest: Új Nemzedék Központ.

Széll K. and Nagy Á. (2018). Oktatási helyzetkép: Iskolai életutak, tervek és lehetőségek [Education report: School trajectories, aspirations and opportunities]. In Nagy Á., ed., Margón kívül: Magyar ifjúságkutatás 2016. Budapest: Excenter Kutatóközpont, pp. 54-97. 
Vaskovics L. (2000). A posztadoleszcencia szociológiai elmélete [The sociological theory of postadolescence]. Szociológiai Szemle, 10(4), pp. 3-20.

Vincze, Sz. (2012). Átmenet az oktatásból a munka világába: Friss diplomások a munkaerőpiacon [Transition from education to employment: Fresh graduates on the labor market]. Iskolakultúra, 22(3), pp. 85-95.

Wallace, C. and Kovatcheva, S. (1998). Youth in society: The construction and deconstruction of youth in East and West Europe. London: MacMillan. 


\section{APPENDIX}

Table A1: Fit indicators for models with different number of latent classes for each step of the analysis

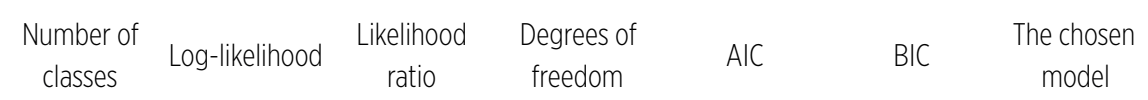

Wave 1 , cross-sectional data

$\begin{array}{rrrrrrr}1 & -1878.6 & 868.3 & 26 & 878.3 & 902.9 & \\ 2 & -1544.3 & 199.7 & 20 & 221.7 & 275.7 & \\ 3 & -1458.8 & 28.8 & 14 & 62.8 & 146.2 & X \\ 4 & -1449.4 & 10.0 & 8 & 56.0 & 168.8 & \\ 5 & -1445.7 & 2.5 & 2 & 60.5 & 202.8 & \end{array}$

Wave 2, cross-sectional data

\begin{tabular}{|c|c|c|c|c|c|c|}
\hline 1 & -2238.7 & 1167.9 & 26 & 1177.9 & 1201.5 & \\
\hline 2 & -1876.9 & 444.3 & 20 & 466.3 & 518.2 & \\
\hline 3 & -1688.4 & 67.2 & 14 & 101.2 & 181.4 & \\
\hline 4 & -1667.0 & 24.5 & 8 & 70.5 & 179.0 & $x$ \\
\hline 5 & -1658.3 & 7.0 & 2 & 65.0 & 201.8 & \\
\hline \multicolumn{7}{|c|}{ Wave 3, cross-sectional data } \\
\hline 1 & -1645.5 & 610.1 & 26 & 620.1 & 642.3 & \\
\hline 2 & -1405.1 & 129.2 & 20 & 151.2 & 200.0 & \\
\hline 3 & -1365.2 & 49.5 & 14 & 83.5 & 159.0 & \\
\hline 4 & -1343.2 & 5.5 & 8 & 51.5 & 153.5 & $x$ \\
\hline 5 & -1341.6 & 2.4 & 2 & 60.4 & 189.0 & \\
\hline
\end{tabular}


Table A7: Fit indicators for models with different number of latent classes for each step of the analysis (continued)

\begin{tabular}{|c|c|c|c|c|c|c|}
\hline $\begin{array}{l}\text { Number of } \\
\text { classes }\end{array}$ & Log-likelihood & $\begin{array}{l}\text { Likelihood } \\
\text { ratio }\end{array}$ & $\begin{array}{l}\text { Degrees of } \\
\text { freedom }\end{array}$ & AIC & $\mathrm{BIC}$ & $\begin{array}{c}\text { The chosen } \\
\text { model }\end{array}$ \\
\hline \multicolumn{7}{|c|}{ Wave 4, cross-sectional data } \\
\hline 1 & -1094.1 & 339.7 & 26 & 349.7 & 370.0 & \\
\hline 2 & -950.6 & 52.7 & 20 & 74.7 & 119.3 & \\
\hline 3 & -928.7 & 8.9 & 14 & 42.9 & 112.0 & $x$ \\
\hline 4 & -925.4 & 2.4 & 8 & 48.4 & 141.7 & \\
\hline 5 & -924.7 & 1.0 & 2 & 59.0 & 176.7 & \\
\hline \multicolumn{7}{|c|}{ Waves 1-4, longitudinal data } \\
\hline 1 & -1890.6 & 734.3 & 133 & 754.3 & 794.9 & \\
\hline 2 & -2776.8 & 331.9 & 122 & 373.9 & 477.0 & \\
\hline 3 & -2700.7 & 179.7 & 111 & 243.7 & 400.7 & \\
\hline 4 & -2664.6 & 107.6 & 100 & 193.6 & 404.6 & $x$ \\
\hline 5 & -2641.8 & 61.9 & 89 & 169.9 & 434.9 & \\
\hline 6 & -2634.2 & 46.7 & 78 & 176.7 & 495.7 & \\
\hline
\end{tabular}

Notes: $\mathrm{AIC}=$ Akaike Information Criterion, $\mathrm{BIC}=$ Bayesian Information Criterion. The main criteria for the choice between models were minimizing AIC and BIC and the preference for simpler models (fewer classes). Cross-sectional models with six or more classes are not presented here as their degrees of freedom are negative, indicating identification problems.

Source: Longitudinal data from the Hungarian Generations and Gender Survey (2001-2013), birth cohort 1981-1983, $n=1000$, author's calculation. 